\title{
Facies development of the Upper Triassic succession on Barentsøya, Wilhelmøya and NE Spitsbergen, Svalbard
}

\author{
Gareth Steven Lord ${ }^{1,2}$, Sondre Krogh Johansen ${ }^{1,2}$, Simen Jenvin Støen ${ }^{1,2} \&$ Atle Mørk
}

\author{
${ }^{1}$ Department of Geoscience and Petroleum, Norwegian University of Science and Technology (NTNU), Sem Selands veg 1, 7491, Trondheim, Norway. \\ ${ }^{2}$ Department of Arctic Geology, University Centre in Svalbard (UNIS), Longyearbyen, 9171, Norway. \\ E-mail corresponding author (Gareth Steven Lord): gareth.lord@ntnu.no
}

\begin{abstract}
Field data collected from the northeasternmost Triassic exposures on the islands of Spitsbergen, Wilhelmøya and Barentsøya during 2015 are used for sedimentological facies analysis to improve our understanding of the stratigraphic development of the Upper Triassic strata. Results presented here build upon previous studies from the eastern areas of the Svalbard archipelago and seek to extend this understanding northward. Paralic deltaic sediments are recognised throughout the field area, and our analysis shows that the Upper Triassic De Geerdalen Formation is composed of three discrete units defined by the differences in gross depositional environments. The lower interval of early Carnian age is dominated by shallow-marine and delta-front/ shoreface deposits, the middle interval of mid Carnian age is dominated by delta-front to delta-top deposits, and the upper interval, corresponding to the Isfjorden Member, of a late Carnian to early Norian age, is dominated by delta-top deposits which include lagoonal and lacustrine deposits. These observations show that the De Geerdalen Formation represents a more distal depositional setting, than the depositional environments previously reported from the islands of Edgeøya and Hopen. We also document the presence of the Tschermakfjellet Formation and Isfjorden Member on Wilhelmøya, thus increasing our understanding of the northwestward development of the Upper Triassic succession in Svalbard.
\end{abstract}

Keywords: Facies Development; Upper Triassic; Eastern Svalbard; Sedimentology

Received 18. January 2017 / Accepted 6. February 2017 / Published online 28. March 2017

\section{Introduction}

The Upper Triassic stratigraphy in Svalbard (Figs. $1 \mathrm{~A}-\mathrm{B} \& 2 \mathrm{~A})$ was first described by Buchan et al. (1965). Preliminary facies studies were given for eastern Svalbard by Flood et al. (1971a) and Lock et al. (1978), whilst Mørk et al. (1982) covered much of the archipelago. Rød et al. (2014) provide the most extensive sedimentological study covering Edgeøya and central Spitsbergen. The succession has largely been regarded as a useful analogue to the Triassic in the Barents Sea, and particularly the comparison to the fluvio-deltaic Snadd Formation, known for its reservoir potential, has received some attention (e.g., Klausen \& Mørk, 2014; Klausen et al., 2014, 2015). Recent sedimentological studies in the Upper Triassic of Svalbard have thus focused primarily on fluvial sandstone bodies seen in the southeastern areas of the archipelago (Solvi, 2013; Klausen \& Mørk, 2014; Lord et al., 2014b), as analogues to potential reservoirs in the Snadd Formation. Mørk (2013) and Anell et al. (2014a, b) discussed the Upper Triassic succession in relation to its potential as a $\mathrm{CO}_{2}$ storage reservoir in central Spitsbergen. However, in these cases the northernmost parts of the Storfjorden area in eastern Spitsbergen have been somewhat disregarded.

In the study area (Fig. 1B), the Carnian succession has not been studied in detail since the earlier works of

Lord, G.S., Johansen, S.K., Støen, S.J. \& Mørk, A. 2017: Facies development of the Upper Triassic succession on Barentsøya, Wilhelmøya and NE Spitsbergen, Svalbard. Norwegian Journal of Geology 97, 33-62. https://dx.doi.org/10.17850/njg97-1-03. 


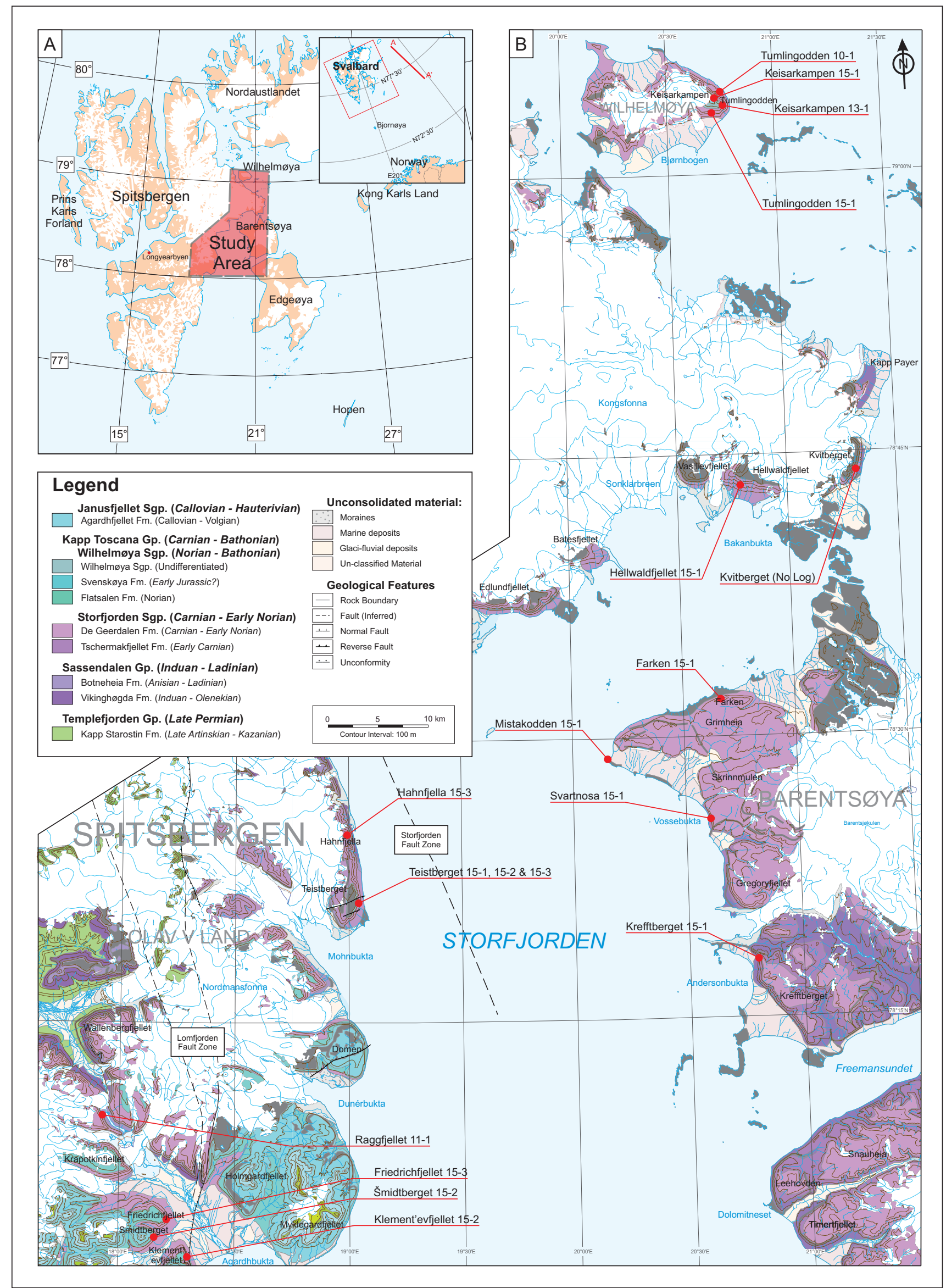

Figure 1. (A) Inset map showing an overview of the high Arctic position of Svalbard in relation to the Barents Sea and Norway. The study area is highlighted in red. Note the location of the seismic line, shown in Fig. 3B. (B) Geological map of the study area featuring the major stratigraphic units, structures and position of measured sections. The map is modified after Dallmann \& Elvevold (2015). 

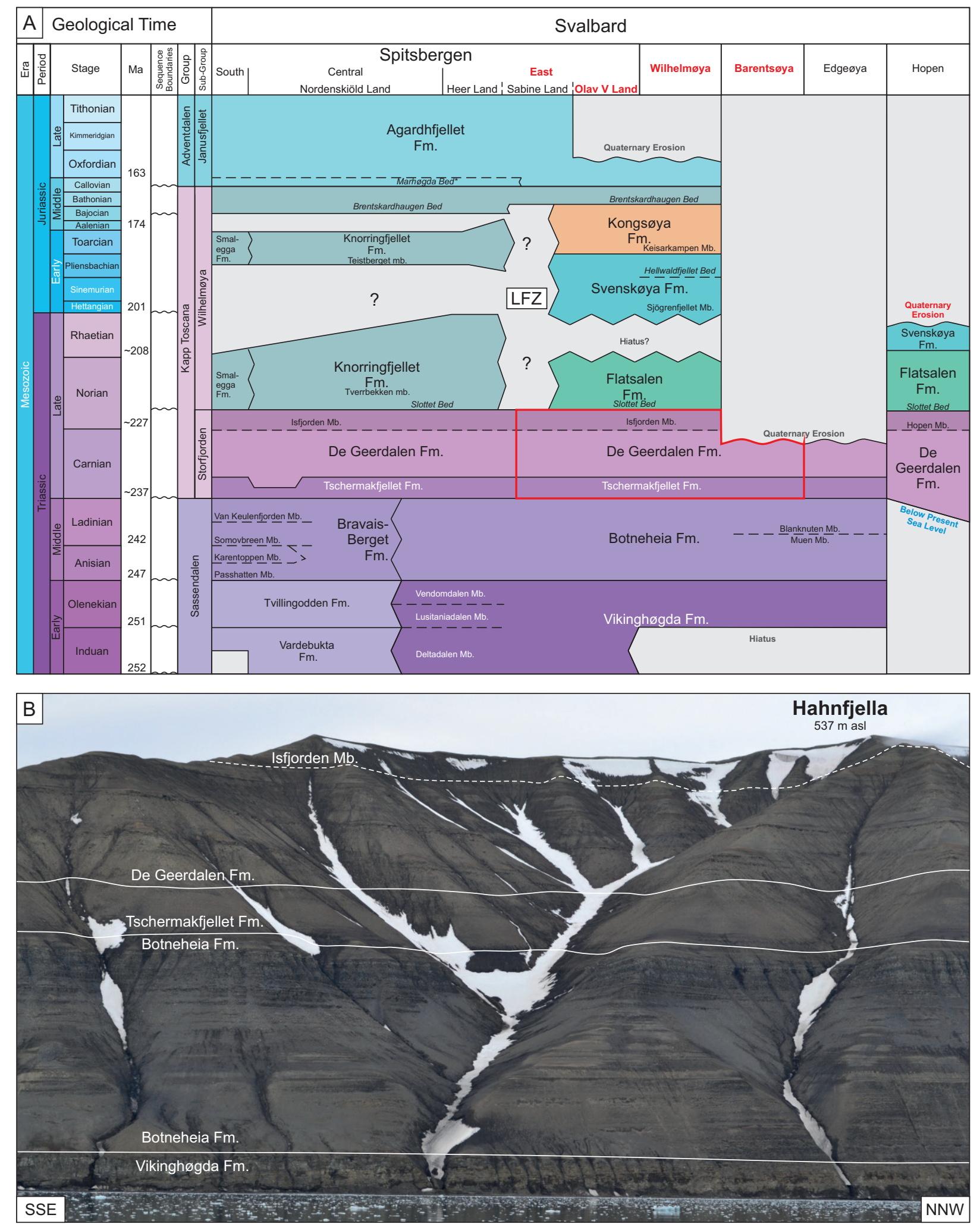

Figure 2. (A) Stratigraphic chart of the Triassic to Middle Jurassic successions at various locations throughout Svalbard (modified after Mørk et al., 1999a, 2013). (B) An overview picture of the mountain of Hahnfjella (Fig. 1B) in eastern Spitsbergen with a well exposed section of the Middle-Upper Triassic succession. The Middle Triassic shales of the Vikinghøgda and Botneheia formations form steep cliffs along the base of the mountain. These are overlain by small upward-coarsening packages in the De Geerdalen Formation. The Isfjorden Member is partially exposed in the upper part of the mountain. 
Flood et al. (1971a), Lock et al. (1978) and Pčelina (1983). These studies primarily focused on the establishment of a stratigraphic scheme and detailed dating. The work by Flood et al. (1971a) covered the main eastern islands of Barentsøya, Edgeøya and Hopen, defining the Vardebukta, Kongressfjellet, Tschermakfjellet and De Geerdalen formations. A brief sedimentological description of each formation is also provided. Importantly, this study recognised the correlation of units from Spitsbergen to the eastern islands.

The stratigraphic terminology for Barentsøya, Edgeøya, Wilhelmøya and Hopen of Flood et al. (1971a, b), Worsley (1973), Smith et al. (1975), Lock et al. (1978), Winsnes (1981), Winsnes \& Worsley (1981), Mørk et al. (1982) and Pčelina (1983) was replaced by the nomenclature now in use by Mørk et al. (1999a), representing a more coherent stratigraphical scheme (Fig. 2A).

Pčelina (1983) proposed the names Hahnfjella and Isfjorden 'suita' (formation), recognising the distinctive change seen in the upper part of the De Geerdalen Formation. The Isfjorden suita was retained, but lowered to member rank, by Mørk et al. (1999a).

This study builds upon the existing stratigraphic and facies frameworks defined for other eastern islands of Svalbard and extend these to the northernmost Upper Triassic exposures. The sedimentological understanding from Hopen (Klausen \& Mørk, 2014; Lord et al., 2014a, b) and Edgeøya (Rød et al., 2014) provide the base framework for this study. Vigran et al. (2014) provided regional biostratigraphic dating that aids in positioning logged sections accurately within the stratigraphy.

The aim of this article is to present findings from recent fieldwork in Svalbard, conducted on the Upper Triassic in easternmost Spitsbergen, Barentsøya and Wilhelmøya (Fig. 1A). The focus has been primarily on the Upper Triassic Tschermakfjellet and De Geerdalen formations. The primary objective is to understand facies distributions within these two formations and relate these to the development of a major deltaic system that has been well documented in other areas in the archipelago and the Barents Sea (Riis et al., 2008; Glørstad-Clark et al., 2010; Høy \& Lundschien, 2011; Klausen \& Mørk, 2014; Rød et al., 2014; Klausen et al., 2014, 2015).

\section{Regional geological setting}

Svalbard is a $61,000 \mathrm{~km}^{2}$ archipelago in the European high arctic and consists of eight main islands with Spitsbergen being the largest (Fig. 1A). The archipelago represents an uplifted corner of the Barents Sea Shelf (Worsley, 2008) and is bound to its north and west by continental margins. The western part of Spitsbergen is dominated by a Cenozoic orogenic belt, whilst the eastern areas, including the study area, are part of a
Palaeozoic-Mesozoic platform area (Riis et al., 2008; Worsley, 2008). The eastern areas of Spitsbergen are dominated by flat-lying strata of Permian to Palaeocene age, intruded by Cretaceous (124.5 Ma; Corfu et al., 2013) dolerite sills and dykes (Dallmann \& Elvevold, 2015). The study area is located in this eastern platform area. Some tectonic features of Palaeozoic and Cenozoic age are present; however, the majority of the study area is undeformed.

In the study area, the Lomfjorden Fault Zone (Fig. 1B) dissects eastern Spitsbergen, in a near north-south orientation from northern Spitsbergen through part of the study area in Agardhbukta. This fault zone comprises a main thrust fault, a dextral strike-slip fault component, and a series of small thrust sheets (Dallmann \& Elvevold, 2015; Dallmann et al., 2015). The Storfjorden Fault Zone (Eiken, 1985), a NNW-SSE lineament, trends through Storfjorden approximately $40 \mathrm{~km}$ to the east of Agardhbukta. The faulting is defined as Permian age or older and is present as normal faulting with a westward dip and throws of up to $1 \mathrm{~km}$ (Eiken, 1985).

In eastern Svalbard, Triassic strata overlie the Upper Permian Kapp Starostin Formation (Mørk et al., 1999a; Dallmann \& Elvevold, 2015). The units of the Lower to Middle Triassic Sassendalen Group are the Vikinghøgda (Induan-Olenekian) and Botneheia (Anisian-Ladinian) formations (Mørk et al., 1999a, b). The Upper Triassic Storfjorden Subgroup is divisible into the Tschermakfjellet and De Geerdalen formations (Buchan et al., 1965; Mørk et al., 1999a). The overlying Upper Triassic to Middle Jurassic Wilhelmøya Subgroup (Worsley, 1973; Mørk et al., 1999a) consists of the Flatsalen, Svenskøya and Kongsøya formations. The Storfjorden and Wilhelmøya subgroups together form the Kapp Toscana Group (Mørk et al., 1999a).

The shales of the Induan to Olenekian Vikinghøgda Formation (Fig. 2B) were deposited in a shallow shelf setting (Mørk et al., 1999a; Dallmann \& Elvevold, 2015). The Middle Triassic Botneheia Formation (Fig. 2A, B), formed of marine shale, is one of the major organicrich units present in Svalbard with a high total organic content of c. 8-10\% (Mørk \& Bjorøy, 1984).

The Botneheia Formation is overlain by the early Carnian Tschermakfjellet Formation (Figs. 2B, 3A), which is a succession of prodelta shale and siltstone. Offshore, this shale-dominated unit is incorporated into the lower part of the Snadd Formation (Lundschien et al., 2014).

The De Geerdalen Formation in Svalbard represents deposition of sediments in a shallow shelf and deltaic environment in an overall paralic setting (Mørk et al., 1982, 1999a, Klausen \& Mørk, 2014; Rød et al., 2014). The base of the unit is defined by the first prominent sandstone above the Tschermakfjellet Formation (Mørk et al., 1999a). The formation largely consists of stacked 

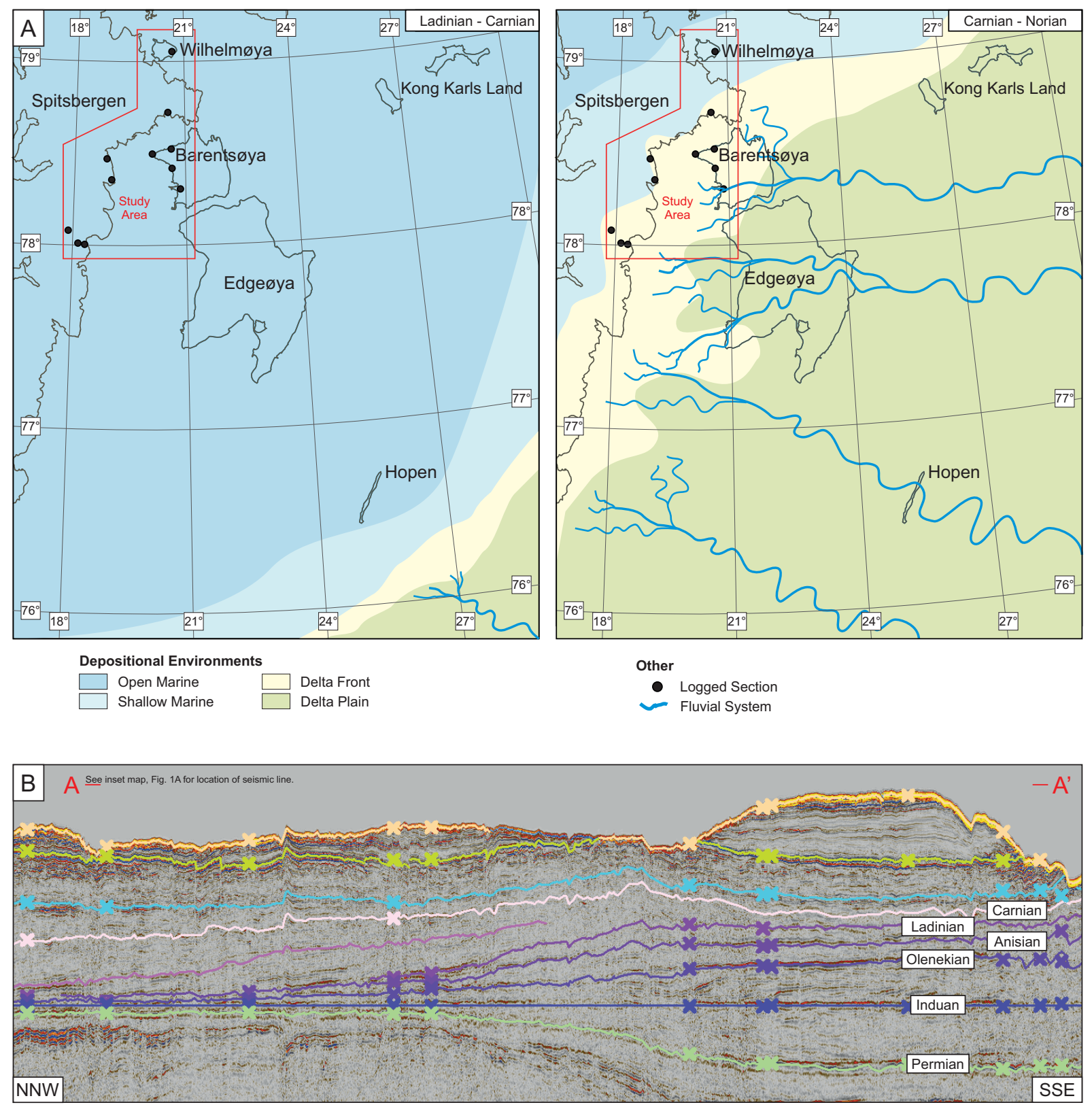

Figure 3. (A) Depositional environments of the southeastern area of Svalbard and the northern Barents Sea showing the infill of sediment throughout the Middle-Late Triassic, after Riis et al. (2008), Lundschien et al. (2014) and Klausen et al. (2015). Open marine conditions prevailed in the study area throughout the Middle Triassic prior to a rapid deltaic advance from the east and southeast during the Carnian. (B) The seismic line (courtesy of NPD) shot to the east of Svalbard, has been flattened on the Induan reflector. The position of the line is marked on the inset map in Fig. 1A. The section shows Middle to Late Triassic clinoforms prograding to the NNW throughout the northern Barents Sea and is in agreement with the studies of Riis et al. (2008), Glørstad-Clark et al. (2010) and Anell et al. (2014a).

upward-coarsening units (parasequences) of deltaic origin (Mørk et al., 1982, 1999a; Rød et al., 2014) and is seen to be most proximal in the area around Hopen, where fluvial trunk channels are observed (Mørk et al., 2013; Klausen \& Mørk, 2014; Lord et al., 2014b). Distal deltaic facies are evident throughout parts of Edgeøya, becoming more dominant in central Spitsbergen (Knarud, 1980; Mørk et al., 1982; Rød et al., 2014). The interpretation of well-defined clinoforms in the northern Barents Sea (Riis et al., 2008; Glørstad-Clark et al., 2010; Høy \& Lundschien, 2011; Anell et al., 2014a, b; Lundschien et al., 2014; Klausen et al., 2015) supports the interpretation of a large deltaic system prograding northwestwards over a shallow shelf.

The upper $70 \mathrm{~m}$ of the De Geerdalen Formation is defined as the Isfjorden Member (Fig. 2A, B; Pčelina, 1983; Mørk et al., 1999a; Haugen, 2016). This member is dominated by siltstone and thin sandstone beds, with red and green nodular clays in its upper part. The unit is correlative to the Hopen Member in easternmost Svalbard (Mørk et al., 2013; Lord et al., 2014a). On Spitsbergen and Wilhelmøya, the Isfjorden Member represents deposition in shallow shelf, lagoonal and 
delta-plain environments (Pčelina, 1983; Mørk et al., 1999a; Haugen, 2016). This part of the succession is eroded on Barentsøya and Edgeøya (Mørk et al., 1999a; Lundschien et al., 2014; Rød et al., 2014).

The base of the early Norian Flatsalen Formation (Wilhelmøya Subgroup) is marked by the Slottet Bed (Fig. 2A; Worsley, 1973; Mørk et al., 1999a), a 2-3 $\mathrm{m}$-thick unit consisting of phosphate conglomerate and carbonate cemented siltstone. The remainder of the Flatsalen Formation is composed of deep-marine shelf shales, which include several minor upward-coarsening units. Marine vertebrate fossils are present throughout (Vigran et al., 2014) and abundant at one interval on Wilhelmøya; and dating by palynology, ammonoids and magnetostratigraphy indicates that the unit is of Norian age (Mørk et al., 1999a; Lord et al., 2014a). The remaining Upper Triassic to Middle Jurassic stratigraphy is represented by the Svenskøya and Kongsøya formations, overlain by the Upper Jurassic Agardhfjellet Formation (Fig. 2A).

\section{Carnian-Norian infill patterns of the Barents Sea}

The deposits of the Carnian De Geerdalen Formation (Figs. 2B, 3A) represent the northwestward progradation of a deltaic system across the Barents Shelf, with its primary source area being the Uralide Mountains in the southeast (Riis et al., 2008; Høy \& Lundschien, 2011; Lundschien et al., 2014; Støen, 2016).

Mineralogical provenance (Mørk, 1999) and detrital zircon studies (Bue \& Andresen, 2013; Fleming et al., 2016) collectively indicate that major portions of Uralian derived sand originate from the northern part of the Ural Mountains, with a minor contribution originating from either the Timanides or another northeastern source in the Taimyr region. Chromium-spinel provenance studies suggest that sandstones in the De Geerdalen Formation are partly derived from volcanic rocks and indicate a source to the northeast or east of Svalbard (Mørk, 1999; Flemming et al., 2016; Harstad, 2016).

The orogenic processes that formed the Uralide Mountains occurred during the Late Devonian to Late Permian (Puchkov, 2009). The mountain belt stretched along the continental margin of the Siberian Terrane, accompanied by a shallow foreland basin. This basin formed an epicontinental sea situated between the Siberian Terrane and the Greenland-American plate (Torsvik \& Cocks, 2004; Riis et al., 2008; Torsvik et al., 2012).

The area of Svalbard was positioned in the northwestern margin of this shelf during the Triassic at approximately $55-60^{\circ} \mathrm{N}$ (Elvevold et al., 2007). A slow northward migration of the northern part of Pangea occurred throughout the Mesozoic, resulting in a shift from subtropical to temperate climates (Elvevold et al., 2007; Worsley, 2008).

The Uralide and Timanide mountains provided sediment to this basin, from the east and southeast (Mørk, 1999; Riis et al., 2008; Glørstad-Clark et al., 2010; Miller et al., 2013). Throughout the Triassic, large rivers and deltaic depositional environments (Fig. 3A) became prominent along the margins of this seaway (Nystuen et al., 2008; Riis et al., 2008, Eide et al., in press), extending northwards to the Svalbard area by the Carnian. The sediment yield was significant enough to infill the basin with large volumes of siliciclastic material and resulted in extensive tidal, deltaic and fluvial deposits forming the Snadd and De Geerdalen formations (Mørk et al., 1982, 1999a; Glørstad-Clark et al., 2010; Klausen \& Mørk, 2014; Lord et al., 2014b; Rød et al., 2014; Enga, 2015).

Progradation of this delta system can be viewed in seismic lines shot to the east and southeast of Svalbard as shown in Fig. 3B (Riis et al., 2008; Glørstad-Clark et al., 2010; Høy \& Lundschien, 2011; Anell et al., 2013, 2014a, b; Lundschien et al., 2014). Several studies have interpreted and mapped a succession of clinoform belts that can be seen to be gently dipping to the northwest. Within this series, Anisian, Ladinian and Carnian age clinoforms have been reported.

\section{Methods}

New field data have been collected during a summer field campaign in 2015, during two separate expeditions. The first expedition was conducted by students and researchers from the Norwegian University of Science and Technology (NTNU), working in the region of Agardhdalen in eastern Spitsbergen. The second was undertaken by the same group throughout eastern Spitsbergen, Wilhelmøya and Barentsøya, in cooperation with geologists from the Norwegian Petroleum Directorate (NPD).

Contemporary sedimentological field studies form the bulk of the data collected during the 2015 field season in the Storfjorden area (Fig. 1B). Sedimentary logs were measured bed-by-bed, and include descriptions of rock type, grain size, sorting, sedimentary structures and the presence of body and trace fossils. Sections were measured at centimetre scale and drawn to $1: 100$ or 1:50 in the field. Logs have been redrawn to 1:1250 scale for ease of presentation. Relevant sections collected from earlier expeditions in 2010, 2011 and 2013 are also included.

The Wilhelmøya Subgroup was not the primary target of the present field studies. Nevertheless, where present, the subgroup has been measured for the key purpose of correlation. The lower parts of the De Geerdalen 
Formation are often scree covered and underlying stratigraphic units are either below the surface or sea level. Throughout Barentsøya the uppermost part of the De Geerdalen Formation has been eroded by Cenozoic uplift and erosion as well as by Quaternary glaciation. Sections without the underlying Botneheia or Tschermakfjellet formations present are thus correlated tentatively. In order to correlate facies correctly in the De Geerdalen Formation, it is necessary to 'flatten' sections on a well-defined datum surface. The basal Slottet Bed to the Wilhelmøya Subgroup (Mørk et al., 1999a) has been chosen for this purpose, as it is seen extensively throughout the study area. Where this unit is not present the boundaries between the Botneheia and Tschermakfjellet formations have been used.

\section{Results}

Facies analysis conducted in this study has subdivided measured sections into individual facies and combined genetically related groups of facies into facies associations (FA) reflecting various subenvironments of deposition. These are then grouped to form an overall depositional environment (DE) that may be recognised at various levels in the stratigraphy and thus correlated across the study area.

\section{Facies}

In total, 14 sedimentary facies are defined within the study area and are summarily presented in Table 1 . The observed facies are an extension of those presented by Klausen \& Mørk (2014) and Rød et al. (2014) in areas farther to the south and east. Facies analyses mainly focus on the Tschermakfjellet and De Geerdalen formations; deposits in the underlying and overlying units are only briefly described.

\section{Facies associations}

The De Geerdalen Formation consists of recurring coarsening- and shallowing-upward successions (Mørk et al., 1982, 1999a), which may be defined as parasequences (sensu Van Wagoner et al., 1990), where delta lobe-switching and subsequent abandonment and transgression have been suggested mechanisms (Mørk et al., 1982; Vigran et al., 2014). In the study area, 11 facies associations have been defined and are constructed from the facies presented. These are summarised in Table 2.

\section{FA 1 - Open shelf deposits}

Description: Units consisting entirely of laminated, normal-graded, fissile shales composed entirely of facies A (Table 1; Fig. 4A). Dolomite and calcite-cemented beds may be present and abundant ammonoids or marine vertebrate fossils are found. A high total organic content is evident, with reported values up to $10 \%$ (Mørk \& Bjorøy, 1984). Phosphate nodules are abundant both as distinctive beds or individual nodules. Septarian concretions are also present.

Interpretation: This facies association is restricted to the Botneheia and Flatsalen formations (Fig. 2A, B) which represent deep-marine shelf and offshore mudstones deposited in the deepest parts of the basin (Mørk et al., 1999a; Krajewski, 2008). Preservation of organic matter, phosphate nodules and ammonoid imprints are interpreted as suggesting dysoxic to anoxic bottom-water conditions (Mørk \& Bjorøy, 1984; Krajewski, 2008; Mørk $\&$ Bromley, 2008). These formations underlie and overlie the Storfjorden Subgroup (Fig. 2A), respectively.

\section{FA 2 - Prodelta slope deposits}

Description: This facies association is composed of normal-graded mudstones and siltstones (Facies A, Table 1; Fig. 4B), sets of upward-coarsening heterolithic bedding (Facies B) and thin $(10-20 \mathrm{~cm})$, normal-graded, sandstone beds with hummocky cross-stratification (Facies C). Siderite concretions are common. Normalgraded, fine-grained, plane parallel-laminated sandstones in thin beds with bioturbation are also seen (Facies $\mathrm{H})$. This facies association typically displays an overall upward-coarsening trend with silt and sandstone beds becoming thicker and more extensive in the upper part.

Interpretation: This facies association is typically restricted to the Tschermakfjellet Formation. The unit is commonly regarded to represent the prodeltaic counterpart to the De Geerdalen Formation (Mørk et al., 1982, 1999a; Lundschien et al., 2014; Rød et al., 2014) and this interpretation is maintained for the study area. The bulk of the mudstone component represents a settling of fine-grained background sediments. A proportion may be derived from far-travelled hypopycnal sediment, which originates from the delta front as diluted, lowdensity flows (Bhattacharya \& MacEachern, 2009; Olariu et al., 2010). Thin hummocky cross-stratified and plane parallel laminated sandstones are interpreted as representing sediment introduced to the delta slope by storm events.

\section{FA 3 - Offshore deposits}

Description: Offshore deposits (Fig. 4C) consist primarily of normal-graded, grey mudstone and siltstone or heterolithic beds (Facies A and B). Beds of 20-30 $\mathrm{cm}$-thick, normal-graded, low-angle cross-laminated sandstone, or tabular cross-laminated sandstone (Facies I and J), are also seen to be interbedded within the finegrained facies. Plant fragments may be found in some sandstone beds and bioturbation is common. This facies association gradually passes laterally into FA 4 .

Interpretation: This facies association is dominated by fine-grained material with sand introduced from the shoreline (Reading \& Collinson, 1996; Myrow et al., 
Table 1. Overview of the 14 facies defined for the Upper Triassic succession on Wilhelmøya, Barentsøya and eastern Spitsbergen, expanded from Rød et al. (2014). Log examples are provided as a key for logs displayed in the correlation panel (Fig. 6).

\begin{tabular}{|c|c|c|c|c|}
\hline & & Log Example & Description & Interpretation \\
\hline A & $\mathrm{m}^{0-}$ & 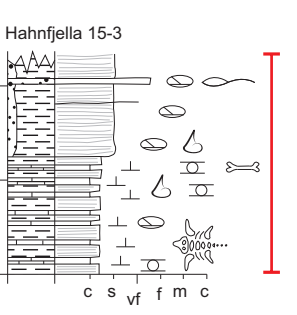 & $\begin{array}{l}\text { Mudstone (0.1-10's m) } \\
\text { Clay and silt, laminated (shale) or non-laminated (mudstone). Thickness } \\
\text { varies from a few centimetres to tens of metres. Laminated mudstones are } \\
\text { most common and may encase thin beds of silty to very-fine sandstone. } \\
\text { Colour is dominantly grey or black, but may also be yellow, white or purple } \\
\text { colour with weathering of siderite cement. } \\
\text { Facies is characterised by horizontal and gently undulating laminae. Load } \\
\text { structures and irregular lamination are occasionally observed. Concretions of } \\
\text { calcite or siderite are common. Organic content may be high at some intervals. } \\
\text { Ammonoids and marine vertebrate fossils are common. }\end{array}$ & $\begin{array}{l}\text { Pelagic shale and mudstone deposited from } \\
\text { suspension in low-energy environments where clay } \\
\text { and silt flocculate and settle on the sea floor } \\
\text { (Boggs, 2011; Collinson et al., 2006). } \\
\text { Also forms background sedimentation in } \\
\text { shallow-marine environments closer to the shoreline. }\end{array}$ \\
\hline B & $\begin{array}{l}90- \\
80- \\
m\end{array}$ & Friedrichfjellet & $\begin{array}{l}\text { Heterolithic Bedding ( } 0.01 \text { - } 10 \text { 's } \mathbf{~ m}) \\
\text { Heterolithic bedding is observed as thin beds of very-fine to fine sandstone } \\
\text { and siltstone alternating with mudstones often forming coarsening-upwards } \\
\text { units. } \\
\text { The thickness of mud and sand layers generally range from } 1 \mathrm{~mm} \text { to a few } \\
\text { centimetres, however thicker packages are evident. } \\
\text { Units are up to } 10-15 \mathrm{~m} \text { thick. Sedimentary structures preserved in the } \\
\text { sandstones of heterolithic successions are commonly hummocky cross- } \\
\text { stratification and ripple cross-stratification. } \\
\text { Bioturbation is common towards the top of units and Skolithos may be present. }\end{array}$ & $\begin{array}{l}\text { Heterolithic bedding indicates alternating flow } \\
\text { regime where sand and mud is available (Davis, } \\
\text { 2012). Mud is deposited from suspension, while } \\
\text { sand is deposited during current or wave activity } \\
\text { (Reineck \& Singh, 1980). This facies can form in the } \\
\text { transition zone when mud interacts with sand } \\
\text { introduced by periods of higher flow and } \\
\text { sedimentation. }\end{array}$ \\
\hline C & $\begin{array}{l}50- \\
\mathrm{m}\end{array}$ & 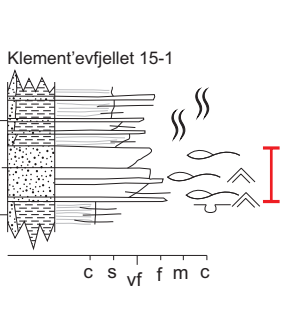 & $\begin{array}{l}\text { Hummocky Cross-Stratified VF-F Sandstone (0.1 - } 1 \mathrm{~m}) \\
\text { Very-fine to fine-grained sandstones featuring hummocky and swaley } \\
\text { cross-stratification. Consists of } 10 \mathrm{~cm} \text { to } 1 \mathrm{~m} \text { thick sandstone beds and are } \\
\text { characterised by cross-laminae in undulating sets. Individual laminae sets are } \\
\text { commonly between } 5 \text { and } 20 \mathrm{~cm} \text { thick. } \\
\text { The sandstones are typically grey to yellow or orange to reddish brown colour. } \\
\text { Beds are usually moderately to intensely bioturbated with Skolithos and } \\
\text { Diplocraterion. Hummocky cross-stratified sandstones are common in } \\
\text { upwards coarsening sequences in the lower part of the De Geerdalen } \\
\text { Formation throughout the study area. }\end{array}$ & $\begin{array}{l}\text { Hummocky cross-stratification shows a distinct } \\
\text { undulating geometry of lamination formed by the } \\
\text { migration of low-relief bed forms in one direction due } \\
\text { to wave surge and unidirectional currents (Nøttvedt } \\
\text { \& Kreisa,1987). } \\
\text { This facies is widely recognised as being } \\
\text { characteristic of tempestite deposition in shallow } \\
\text { marine, storm-dominated inner shelf, to lower } \\
\text { shoreface settings (Midtgaard, 1996; Yang et al., } \\
\text { 2006). Hummocks form below the fair weather wave } \\
\text { base and above, but are most common near storm } \\
\text { weather wave base (Dumas \& Arnott, 2006). }\end{array}$ \\
\hline D & $\begin{array}{l}50^{-} \\
\mathrm{m}\end{array}$ & Mistakodden 15-1 & $\begin{array}{l}\text { Sandstone with Soft Sediment Deformation (0.3-1.5 m) } \\
\text { Erosive based, very-fine to fine-grained sandstones characterised by } \\
\text { abundant soft-sediment deformation. Units can be laterally restricted but } \\
\text { also extensive thickness ranges from } 0.3 \text { to } 1.5 \mathrm{~m} \text {. Irregular lamination } \\
\text { seen within the sandstone bodies are also present in the upper parts of the } \\
\text { underlying, deformed, mudstones. } \\
\text { Sandstones are typically green-grey in colour and lack bioturbation. } \\
\text { Soft-sediment deformed beds are relatively rare throughout the study area, } \\
\text { with the most extensive beds occurring at the locality of Mistakodden. }\end{array}$ & $\begin{array}{l}\text { Soft-sediment deformation structures typically } \\
\text { generate from gravitational processes such as } \\
\text { downslope sliding and slumping or rapid loading of } \\
\text { sediment (Reineck \& Singh, 1980; Bhattacharya \& } \\
\text { MacEachern, 2009). } \\
\text { Likely form the base of distributary mouth bar } \\
\text { deposits, where large volumes of sediments are } \\
\text { deposited rapidly in front of distributary systems and } \\
\text { reworked by wave or fluvial processes. }\end{array}$ \\
\hline $\mathbf{E}$ & 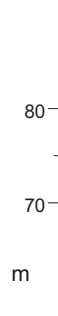 & Mistakodden $15-1$ & $\begin{array}{l}\text { Wave Rippled Sandstone (0.1-4 m) } \\
\text { Very-fine to fine-grained sandstone with symmetrical ripple lamination. } \\
\text { Thicknesses range from tens of cm up to ca. } 4 \mathrm{~m} \text {, individual beds can be } 10 \text { to } \\
30 \mathrm{~cm} \text { in thickness. Sandstones have grey, yellow or red weathering colour. } \\
\text { Fresh surfaces are light grey. Carbonate cement (calcite/ dolomite) or siderite } \\
\text { is common. } \\
\text { Sandstone beds of this facies are normally graded and wave ripples are often } \\
\text { observed on the upper surfaces in coarsening-upwards successions. The } \\
\text { crests tend to be continuous and straight. Mud drapes are common and } \\
\text { expose ripple foresets. Facies is commonly found interbedded with } \\
\text { heterolithic bedding or overlying horizontally bedded sandstone. Moderate } \\
\text { bioturbation and Rhizocorallium or Skolithos trace fossils are present. }\end{array}$ & $\begin{array}{l}\text { Wave ripples are commonly found in shallow- } \\
\text { marine settings. They are formed by the oscillatory } \\
\text { movement of currents at normal wave base (upper } \\
\text { shoreface) where swash and backwash currents } \\
\text { produce symmetrically shaped ripples (Boggs, } \\
\text { 2011). Mud drapes on the foresets of ripples } \\
\text { indicate a tidal influence. }\end{array}$ \\
\hline $\mathbf{F}$ & $\begin{array}{l}30^{-} \\
20^{-} \\
\mathrm{m}\end{array}$ & is & $\begin{array}{l}\text { Current Rippled Sandstone (0.1- } \mathbf{4} \mathrm{m}) \\
\text { Very-fine to fine-grained sandstone with asymmetric ripples forming } \\
\text { individual beds or units composed entirely of ripple cross stratification up to } \\
4 \mathrm{~m} \text { in thickness. Sandstone is yellow, orange and brownish colour. } \\
\text { Sandstone beds in this facies are typically normally graded and have sharp } \\
\text { lower contacts, whereas contacts to upper facies are gradual. In some } \\
\text { instances this facies may fine upwards. Facies is often observed to overlay } \\
\text { large-scale cross-bedded and small-scale cross-bedded, normally graded } \\
\text { sandstones and itself is overlain by fining-upwards beds of horizontally } \\
\text { bedded sandstone. }\end{array}$ & $\begin{array}{l}\text { Current ripples occur with the aggradation of ripples } \\
\text { under contemporary downstream migration during } \\
\text { unidirectional flow. Sets arranged into climbing } \\
\text { ripples form under the same regime but with the } \\
\text { angle of climb reflecting rate of aggradation } \\
\text { (Collinson et al., 2006). } \\
\text { Current ripples are commonly found in environments } \\
\text { such as fluvial floodplains, with sub-environments } \\
\text { such as; crevasse splays and point bars. They are } \\
\text { also present in seasonally flooded river deltas } \\
\text { (Reading \& Collinson, 1996; Boggs, 2011). In marine } \\
\text { environments they are usually formed in the shoaling } \\
\text { wave zone. }\end{array}$ \\
\hline G & $\begin{array}{l}200 \\
\mathrm{~m}\end{array}$ & $\begin{array}{ccccc}\text { Friedrichfjellet } 15-3 \\
\end{array}$ & $\begin{array}{l}\text { Carbonate Cemented Sandstone (0.2-2 m) } \\
\text { Very-fine to fine-grained, normally graded, sandstones characterised by } \\
\text { structures formed during diagenesis. Sandstone units are commonly hard and } \\
\text { heavily cemented with calcite, dolomite or siderite, making observations of } \\
\text { primary sedimentary structures difficult, thickness is typically } 0.2-2 \mathrm{~m} \text {. } \\
\text { Secondary sedimentary structures include cone-in-cone, siderite beds and } \\
\text { calcareous concretions. Colour variation between grey, brown and red are } \\
\text { observed. Scarce to heavy bioturbation is noticed. Cemented sandstone } \\
\text { forms benches in the topography or distinctive layers, that may be laterally } \\
\text { continuous for several tens of metres prior to pinching out. }\end{array}$ & $\begin{array}{l}\text { Sources of calcite cement may be dissolved bivalves } \\
\text { and coquinas. Recent studies by Tugarova \& } \\
\text { Fedyaevsky (2014) suggests a genesis driven by } \\
\text { micro-organisms and a biochemical precipitation of } \\
\text { carbonates during early diagenesis in a } \\
\text { shallow-marine environment. } \\
\text { Siderite occurs in organic-rich brackish to meteoric } \\
\text { pore-waters depleted of } \mathrm{SO}_{2} \text { and is commonly found } \\
\text { in fine-grained deltaic to coastal sediments (Morad, } \\
\text { 1998). Siderite concretions and layering might } \\
\text { indicate a continental influence on marine } \\
\text { sedimentation with organic-rich stagnant waters } \\
\text { close to the delta front (Pettijohn et al.,1987). }\end{array}$ \\
\hline
\end{tabular}


Table 1. Cont.

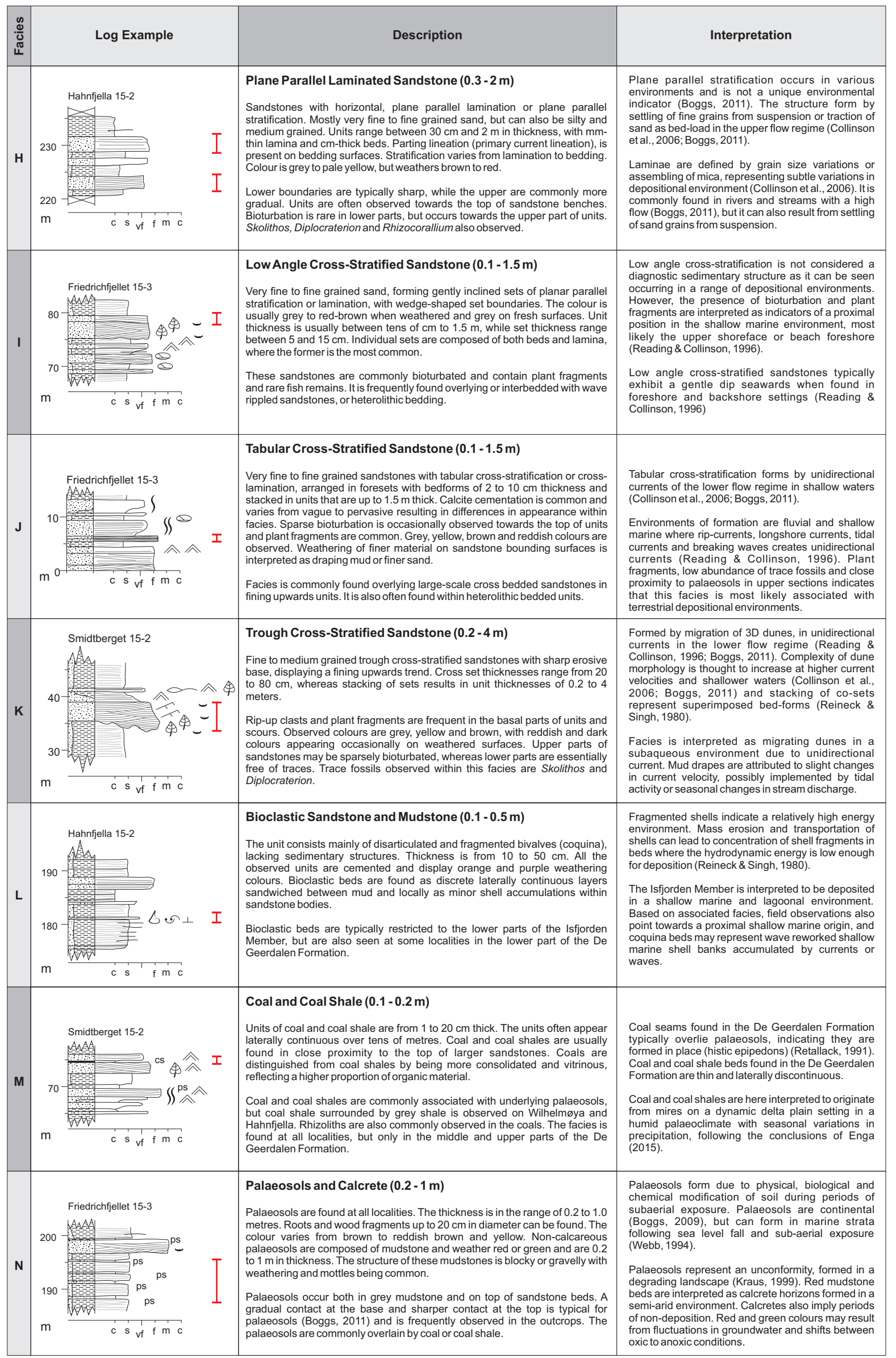



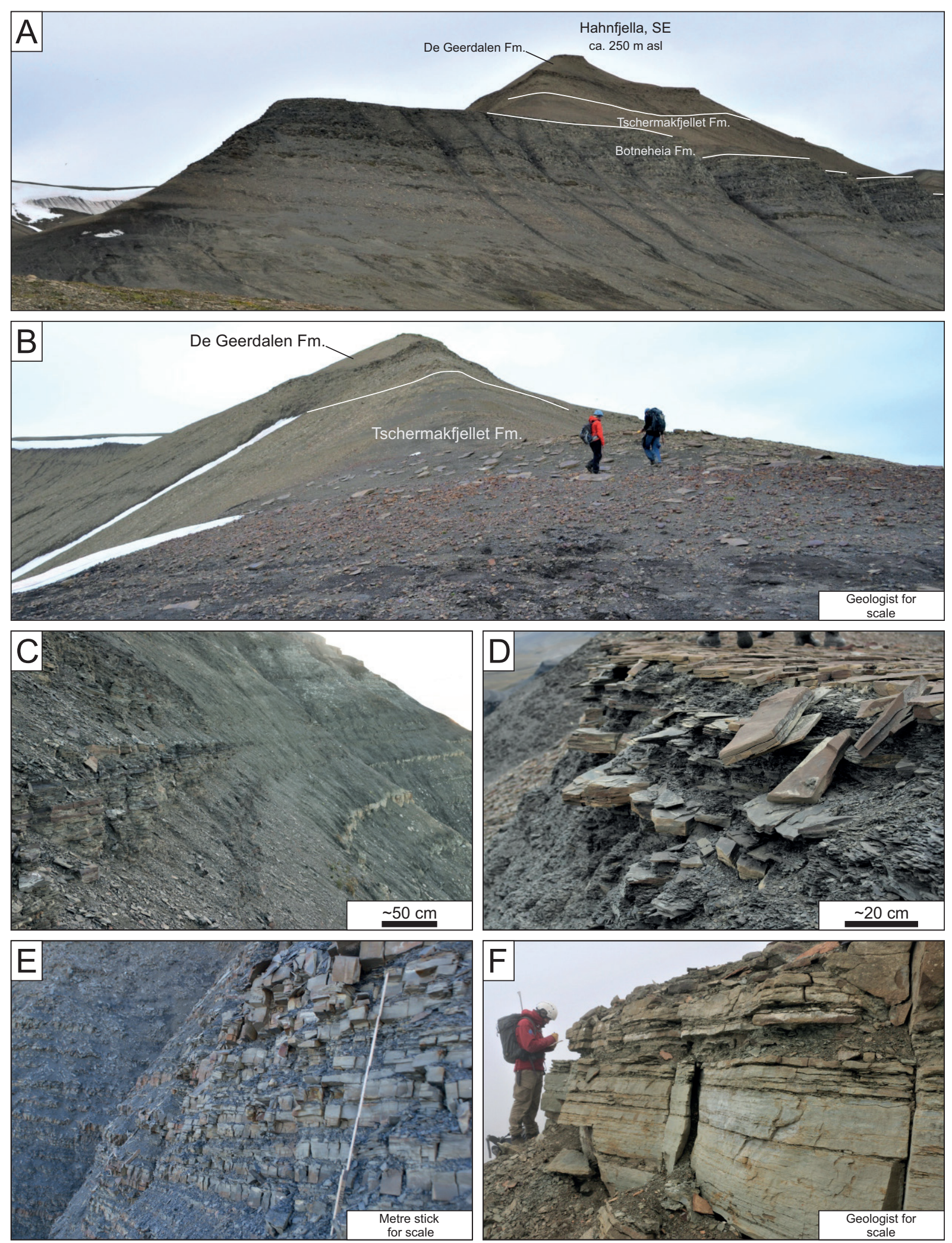

Figure 4. (A) Overview photo of the western ridge of Hahnfjella (Fig. 1B) showing the thick and laterally extensive deposits of FA 1 (Table 2) that typically characterise the Botneheia Formation. (B) FA 2, prodelta shales of the Tschermakfjellet Formation at Hahnfjella. The unit typically consists of facies A, B, C and H (Tables 1, 2). (C) Offshore deposits (FA 3) observed in the upper part of Friedrichfjellet, Agardhbukta (Fig. 1B). This interval represents sedimentation in a shallow-marine environment in a distal setting with dark-grey shales (Facies A) being the dominant lithology. (D) Offshore transition deposits (FA 4) showing thin beds of carbonate-cemented sandstone in the upper part, bearing hummocky cross-stratification (Facies C), with dark-grey shales (Facies A) representing background sedimentation. (E) Heterolithic bedding observed in lower shoreface deposits (FA 4); this facies association represents deposition of sand and silt in a periodically turbulent environment. This periodic turbidity has resulted in heterolithic coarsening-upward units, composed of mudstone and sandstone. Hummocky cross-stratified and waverippled sandstones are common. (F) Upper shoreface deposits (FA 6) featuring sandstone with low-angle, cross-stratification overlain by beds of wave-rippled sandstone (Facies I). Mud drapes are common in the upper parts of these units and are seen to drape ripple crests. 
Table 2. Summary of facies associations (FAs) recognised in the De Geerdalen Formation. The subenvironments are further classified according to their gross depositional environment (DE).

\begin{tabular}{|c|c|c|c|c|}
\hline DE & Facies Association (FA) & $\begin{array}{l}\text { Facies } \\
\text { Incorporated }\end{array}$ & Description & $\begin{array}{l}\text { Geometry } I \\
\text { Form }\end{array}$ \\
\hline \multirow{2}{*}{ 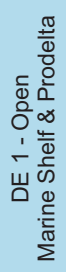 } & FA 1 - Open Marine Shelf Deposits & A & $\begin{array}{l}\text { Pelagic, organic rich shales and marine shale deposits. } \\
\text { Abundant fossils and bone fragments and thin } \\
\text { interlaminae of silt. }\end{array}$ & $\begin{array}{l}\text { Extensive in thickness and } \\
\text { areal extent. Forms major } \\
\text { units. }\end{array}$ \\
\hline & FA 2 - Prodelta Slope Deposits & $\begin{array}{c}A, B, C \\
\& H\end{array}$ & $\begin{array}{l}\text { Marine shales and siltstones, minor sand and } \\
\text { bioturbation. Tempestites may be present with minor } \\
\text { hummocky cross-stratification and ripples. }\end{array}$ & $\begin{array}{l}\text { Areally extensive throughout } \\
\text { Svalbard. Forms stratigraphic } \\
\text { unit with variable thickness. } \\
(10-130 \mathrm{~m}) \text {. }\end{array}$ \\
\hline \multirow{3}{*}{ 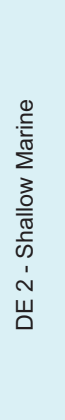 } & FA 3 - Offshore Deposits & $\mathrm{A}, \mathrm{I} \& \mathrm{~J}$ & $\begin{array}{l}\text { Mud and silt dominated distal deltaic sediments. Forms } \\
\text { dark mudstone and heterolithic bedded units with minor } \\
\text { storm induced sandtsones and thin offshore bars. }\end{array}$ & $\begin{array}{l}1-10 \text { 's of metres thick. } \\
\text { Laterally extensive and grade } \\
\text { into offshore transition or lower } \\
\text { shoreface deposits. }\end{array}$ \\
\hline & FA 4 - Offshore Transition Deposits & $\begin{array}{l}A, B, C \\
\& E\end{array}$ & $\begin{array}{l}\text { Thin beds of hummocky cross-stratificatied sandstone } \\
\text { in fine-grained shale and stiltstones. Wave and } \\
\text { symmetrical ripples common. Bioturbation and shell } \\
\text { fragments also present. }\end{array}$ & $\begin{array}{l}1-10 \mathrm{~m} \text { thick, laterally } \\
\text { extensive for } 100 \text { 's } \mathrm{m} \text {. Grades } \\
\text { laterally into offshore or lower } \\
\text { shoreface deposits }\end{array}$ \\
\hline & FA 5 - Lower Shoreface Deposits & $\begin{array}{l}\text { A, B, C, } \\
E, G \& H\end{array}$ & $\begin{array}{l}\text { Below normal wave base deposits dominated by } \\
\text { mudstone and siltstone, with storm induced sandstone } \\
\text { beds. Wave rippled, carbonate cemented or plane } \\
\text { parallel laminated sandstone beds are common. }\end{array}$ & $\begin{array}{l}1-5 \mathrm{~m} \text { thickness and laterally } \\
\text { extensive. Grades laterally } \\
\text { into upper shoreface deposits } \\
\text { or fluvial distributary deposits. }\end{array}$ \\
\hline \multirow{3}{*}{ 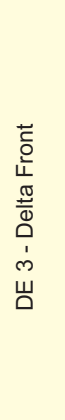 } & FA 6 - Upper Shoreface Deposits & $\begin{array}{l}\text { C, E, F, I \& K } \\
\text { (also G \& L) }\end{array}$ & $\begin{array}{l}\text { Sandstone and siltstone, showing re-working of } \\
\text { sediment in a turbulent environment. Wave structures } \\
\text { indicate marine processes. Mud drapes suggest tidal } \\
\text { influence. Forms prominent sandstone benches. }\end{array}$ & $\begin{array}{l}1-5 \mathrm{~m} \text { thick and laterally } \\
\text { extensive. Overlies lower } \\
\text { shoreface or off shore } \\
\text { transition deposits. }\end{array}$ \\
\hline & $\begin{array}{c}\text { FA } 7 \text { - Distributary Mouth Bar } \\
\text { Deposits }\end{array}$ & $\begin{array}{l}\mathrm{D}, \mathrm{F}, \mathrm{H}, \mathrm{I} \\
\mathrm{J} \& \mathrm{M}\end{array}$ & $\begin{array}{l}\text { Soft sediment deformed sandstone with trough, low- } \\
\text { angle and tabular cross-stratified sandstones. Erosive } \\
\text { base indicate rapid deposition. Reworking of sediment } \\
\text { by wave or tide processes evident. Also amalgamated. }\end{array}$ & $\begin{array}{l}\text { Laterally extensive sheets for } \\
100 \text { 's of } \mathrm{m} \text {. Thickness varies } \\
\text { but is in the order of } 1-4 \mathrm{~m} \text {. } \\
\text { Grades into distributary facies. }\end{array}$ \\
\hline & FA 8 - Barrier Bar Deposits & $\begin{array}{l}\mathrm{E}, \mathrm{F}, \mathrm{H}, \mathrm{I} \\
\& \mathrm{~K}\end{array}$ & $\begin{array}{l}\text { Upwards coarsening facies, with trough or low angle } \\
\text { cross-stratified sandstone, with current or wave rippled } \\
\text { sandstone. Tidal indicators and bioturbation suggest a } \\
\text { marine origin. }\end{array}$ & $\begin{array}{l}\text { Laterally extensive. Thickness } \\
\text { ca. } 1-2 \mathrm{~m} \text {. Grades laterally } \\
\text { into shoreface or inter } \\
\text { distributary deposits. }\end{array}$ \\
\hline \multirow{3}{*}{ 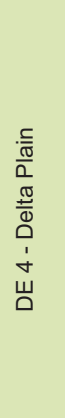 } & FA 9 - Distributary Channel Deposits & $\begin{array}{l}F, H, J, K \\
M \& N\end{array}$ & $\begin{array}{l}\text { Sharp erosive base, contains trough and tabular cross- } \\
\text { stratified sandstone facies. Mud-flakes are common in } \\
\text { this association. Often underlies palaeosol facies. Can } \\
\text { also form lateral sheets with amalgamated channels. }\end{array}$ & $\begin{array}{l}\text { Extensive sandstone bodies. } \\
\text { Often less than } 10 \mathrm{~m} \text { in } \\
\text { thickness. Grades laterally into } \\
\text { floodplain deposits. }\end{array}$ \\
\hline & FA 10 - Floodplain Deposits & $\begin{array}{l}A, E, F, J \\
M \& N\end{array}$ & $\begin{array}{l}\text { Fine-grained floodplain deposits, or overbank fines. Silt } \\
\text { with sandstone laminae common. Coal,coal shale and } \\
\text { palaeosols present in this FA. }\end{array}$ & $\begin{array}{l}\text { Laterally extensive with } \\
\text { variable thickness, ca. } 0.2-1.5 \\
\mathrm{~m} \text {. Overlies or insciced by } \\
\text { fluvial distributary deposits. }\end{array}$ \\
\hline & FA 11 - Inter-distributary Areas & $\begin{array}{c}\text { A, L, M \& N } \\
\text { (with E, F \& H) }\end{array}$ & $\begin{array}{l}\text { Fine-grained facies. Some rare sandstone incursions } \\
\text { with hummocks or ripples may be present, facies } \\
\text { generally suggest a low energy marine or lacustrine } \\
\text { environment. Bioturbation and palaeosols common. }\end{array}$ & $\begin{array}{l}1-10 \text { 's of metres thick, } \\
\text { laterally extensive, grading } \\
\text { laterally into shoreface or } \\
\text { barrierbar deposits. }\end{array}$ \\
\hline
\end{tabular}

2008; Ichaso \& Dalrymple, 2009; Boggs, 2011). The offshore zone is defined as shelf areas below storm wave base and is primarily the site of deposition of fine mud and silt settling from suspension (Bhattacharya, 2006; Nichols, 2009). Bioturbation occurs, and may be locally intense. The offshore zone is well oxygenated, resulting in a typically grey colour of the sediments, partly due to preservation of some organic matter in the mud (Nichols, 2009). Sandstone beds within this FA may represent storm-induced deposits where coarser clastic sediment has been reworked from proximal areas.

This facies association is commonly seen to occur at the base of shallowing-upward parasequences that are common in the De Geerdalen Formation (Mørk et al., 1982). Beds composed of FA 3 mark the onset of flooding (flooding surface) during transgressive episodes. FA 3 can commonly be seen to overlie FAs 9 and 10.

\section{FA 4 - Offshore transition deposits}

Description: Offshore transition deposits in the study area (Fig. 4D) typically consist of normal-graded mudstone (Facies A) or upward-coarsening heterolithic bedding (Facies B), hummocky cross-stratification (Facies C) and wave-rippled sandstones (Facies E). This 
facies association generally forms an overall upwardcoarsening unit, with an increasing thickness of sandstone beds. Heterolithic beds usually feature finegrained sandstone with hummocky cross-stratification. Wave ripples are commonly preserved on the upper bed surface. The mudstones and sandstones commonly display evidence for bioturbation in the form of vertical or semihorizontal burrows (e.g., Skolithos, Diplocraterion or Rhizocorallium). This facies association is typically underlain by offshore zone deposits (FA 3) and overlain by lower shoreface deposits (FA 5), or passes laterally into these FAs.

Interpretation: Due to the overall heterolithic character of deposits in this FA, the presence of hummocky cross-stratification and marine trace fossils, this facies association is interpreted to be representative of the offshore transition zone. This zone extends from the offshore zone, below storm wave base, to depths where storm waves begin to agitate sediments. It is more sandrich compared to the offshore zone and is dominated by alternating energy conditions (Reading \& Collinson, 1996; Dashtgard et al., 2012). Storms generally control sediment distribution in the offshore transition zone by erosion of the coastline. Fine sediments (background sedimentation) are deposited from suspension during fair weather conditions. Typical signatures of storm deposits are a basal lag of coarse sediments, hummocky cross-stratification, wave-rippled cross-lamination and burrowed intervals (Johnson \& Baldwin, 1996; Dashtgard et al., 2012). Bioturbation tends to decrease from proximal to distal settings.

\section{FA 5 - Lower shoreface deposits}

Description: The lower shoreface deposits (Fig. 4E) typically feature normal-graded mudstone in the lower part (Facies A) with an upwards increase of siltstone and sandstone into heterolithic beds (Facies B). Thin, normal-graded sandstone beds, featuring hummocky cross-stratified, wave-rippled and plane parallel stratified, very fine-grained sandstones are present (Facies $\mathrm{C}, \mathrm{E}$ and $\mathrm{H}$ ). Wave-rippled sandstones (Facies E) and plane parallel stratified sandstones (Facies $\mathrm{H}$ ) cap upward- coarsening units and are seen to be laterally discontinuous and interfinger with heterolithic beds or mudstone (Facies A and B). Top surfaces may also show eroded wave crests. Wave-ripple troughs are commonly mud draped and slight bioturbation is present. Calcitecemented sandstones with cone-in-cone structures (Facies G) are also found. This facies association commonly forms the middle part of upward-coarsening parasequences in the lower part of the De Geerdalen Formation.

Interpretation: The lower shoreface deposits feature a higher sand content than in the offshore transition deposits (FA 4) due to the constant reworking of finer grain sizes by oscillatory currents, under fair weather conditions (Clifton, 2006). Wave ripples shallow into current ripples, but can be reworked by storm events resulting in hummocky cross-stratification (Reading \& Collinson, 1996; Dumas \& Arnott, 2006). Interbedded mudstones and mud drapes are indicative of alternating energy conditions and could also be attributed to a tidal influence (Davis, 2012).

\section{FA 6 - Upper shoreface deposits}

Description: Upper shoreface deposits (Fig. 4F) typically include very fine and fine-grained, normal-graded sandstones, dominated by low-angle and trough crossstratified fine-grained sandstone (Facies I and K). Units typically coarsen upwards from the heterolithic part of FA 5. The upper parts of sandstone units feature wave and current ripples (Facies E and F). Bioturbation is also common. Fragmented and disarticulated bivalves and shell fragments may also be found forming thin bioclastic sandstone and mudstone beds (Facies L). Carbonate-cemented sandstone beds (Facies G) may be present and form laterally extensive sandstone beds that form prominent 'benches' in the topography.

Interpretation: The upper shoreface is dominated by wave processes with deposition of sediment occurring above normal wave base. Wave-agitated sediment forms beaches and berms, while fragmented shell beds indicate a high-energy environment. These wave processes typically form seaward-dipping cross-stratification (Scholle \& Spearing, 1982). Shell banks are often located on beaches subjected to intense wave reworking. Massive erosion and transportation of shells can lead to concentration of shell fragments in beds where the hydrodynamic energy is low enough for deposition (Reineck \& Singh, 1980). Individual beds of bioclastic mudstone and sandstone are observed throughout the study area and may represent shell banks (coquina beds) deposited under high-energy conditions.

\section{FA 7 - Distributary mouth bar deposits}

Description: The distributary mouth-bar facies (Fig. 5A) association consists of normal-graded, fine to mediumgrained sandstones, arranged into coarsening-upward units up to $10 \mathrm{~m}$ thick, typically overlying or incising into the heterolithic facies associations of FAs 2 to 5. Softsediment deformed sandstone (Facies D) can be observed to scour into underlying shale beds (FA 3). Low-angle cross-stratified sandstone (Facies I) and tabular crossstratified sandstones (Facies J) are common in the middle and upper parts of these units. Plane parallel laminated sandstones (Facies $\mathrm{H}$ ) and occasional interbedded waverippled and current-rippled sandstones (Facies E and F) are commonly found in the upper parts of sandy units. Abundant plant fragments and coal drapes are found in this facies association. Bioturbation is rarely observed. The sandstone bodies of this FA can also be seen to form amalgamated and laterally extensive sandstone sheets (Fig. 5A) or lenticular sandstone bodies. These are often incised by FA 9 (Distributary channel deposits) or are directly overlain by coaly and coal shale (Facies M, delta- 
plain deposits FA 10).

Interpretation: Rapid deposition rates are common for distributary mouth bars (Reineck \& Singh, 1980), with this illustrated by ripple-laminated sandstones and loading structures. Plane parallel laminated, low-angle crossstratified and wave-rippled sandstones are commonly found in the upper part of this facies association. This indicates wave reworking of deposits. A marine affiliation is supported by marine trace fossils, the low abundance being explained by a rapid influx of fresh water and turbid waters rich in suspended fines. Abundant plant fragments and coal-draped foresets indicate a proximal terrestrial influence, while beds of mudstone forming the heterolithic component of this facies association are likely a result of variations in fluvial discharge. Coal and coaly shale caps indicate an extended period with a high water table, resulting in mires and wetlands and may represent the onset of a transgressive regime.

Distributary mouth bars form at the seaward limit of distributary channels as the flow decelerates, depositing sandy shoals (Reading \& Collinson, 1996; Tye, 2004; Olariu \& Bhattacharya, 2006). Laterally extensive sheets form as waves straighten and elongate the mouth bar alongshore (Reynolds, 1999; Bhattacharya \& Giosan, 2003). Down-cutting of the associated distributary channel commonly erodes the upper parts of mouth-bar sediments (Reading \& Collinson, 1996).

\section{FA 8 - Barrier bar deposits}

Description: Barrier bar deposits (Fig. 5A) can be observed above the heterolithic deposits of FA 2 to 6 . Fine to medium-grained sandstone is found in large-scale, trough cross-stratified units (Facies $\mathrm{K}$ ) in the upper part of parasequences. Low-angle cross-stratified sandstone (Facies I) and plane parallel laminated sandstone (Facies H) may also be present. Small-scale current-rippled sandstones (Facies F) and wave-rippled sandstones (Facies E) are also found in this interval, but compose finer sandstone fractions with minor inclusions of intercalated mud. Tidal signatures such as mud-draped foresets and double mud drapes are observed. Calcite cementation is common and Skolithos and Diplocraterion trace fossils are found within this facies association.

Interpretation: The presence of laterally extensive sandstone benches overlying heterolithic deposits, with low-angle cross-stratification and extensive bioturbation suggests that they represent barrier bar deposits formed in an open clastic coastline (e.g., Clifton, 2006). The units exhibit an upward-shallowing succession of sandstonedominated deposits, overlying distal marine offshore to lower shoreface deposits (FA 1) and underlying proximal nonmarine facies. On the upper shoreface, fair-weather waves set up longshore and onshore currents, leading to migration of bars and current ripples.

Barrier island formations have traditionally been associated with low sediment supply and relative sealevel rise, e.g., a transgressed and submerged delta lobe after upstream avulsion (Reading \& Collinson, 1996; Olariu, 2014). This interpretation can be debated (e.g., Bhattacharya \& Giosan, 2003; Li et al., 2011) as barrier islands can also be attributed to significant delta asymmetry, and are common elements in wavedominated deltas, characterised by strong longshore drift. Mechanisms such as autogenic process change from fluvial to wave-dominated have previously been suggested to explain the coarsening-upward parasequences seen in the De Geerdalen Formation (Mørk et al., 1982). Recurrent barrier bars are seen to form vertically stacked parasequences in the lower parts of measured sections.

\section{FA 9 - Distributary channel deposits}

Description: Distributary channel deposits (Fig. 5C) form prominent sandstone units, either as thin and laterally extensive sheets, or amalgamated into channel complexes that form the upper parts of lenticular sandstone bodies typically incising into FA 7. Rarely, isolated channel deposits may be observed but only in the Isfjorden Member. Sandstones of this facies association feature an erosive base, commonly containing a mud-flake conglomerate lag and abundant plant fragments. Lower parts are dominated by trough cross-stratified intervals (Facies K, Table 1), while tabular cross-stratified sandstones (Facies J, Table 1) and current-rippled sandstones (Facies F, Table 1) are found in the uppermost beds. Muddraped foresets are occasionally seen in trough crossstratified intervals and on ripple crests, but generally mud is restricted to interbedded clay laminae in plane parallel laminated sandstone (Facies $\mathrm{H}$ ). Rootlets, coal and palaeosols (Facies $\mathrm{M}$ and N, Table 1) are found at the very tops of sequences.

Interpretation: Distributary channels carry sediment and water discharge from trunk rivers over the delta plain, to the sea. Distributary channels merge with coastal waters on the delta front and become shallower, branch into subchannels and lose competence (Reineck \& Singh, 1980; Olariu \& Bhattacharya, 2006). Distributary channels are prone to avulsion, bifurcation and anastomose due to the lower slope gradient on the delta plain. Their base is typically erosive with a lag that gradually fines upwards from cross-stratified sandstone to ripple-laminated fine sandstone with alternating silt and clay. Observed rootlets or palaeosols on the top indicate emergence of the channel (Reading \& Collinson, 1996) and likely abandonment of the fluvial system at that location. The width to depth ratio is also small for distributary channels because of their relatively short lifetime and limited time to migrate laterally (Reading \& Collinson, 1996).

Distributary channel deposits tend to be laterally restricted, displaying relatively modest dimensions (height around 2 to 3 metres, width around $10 \mathrm{~m}$ ). However, amalgamated channel deposits show extensive 

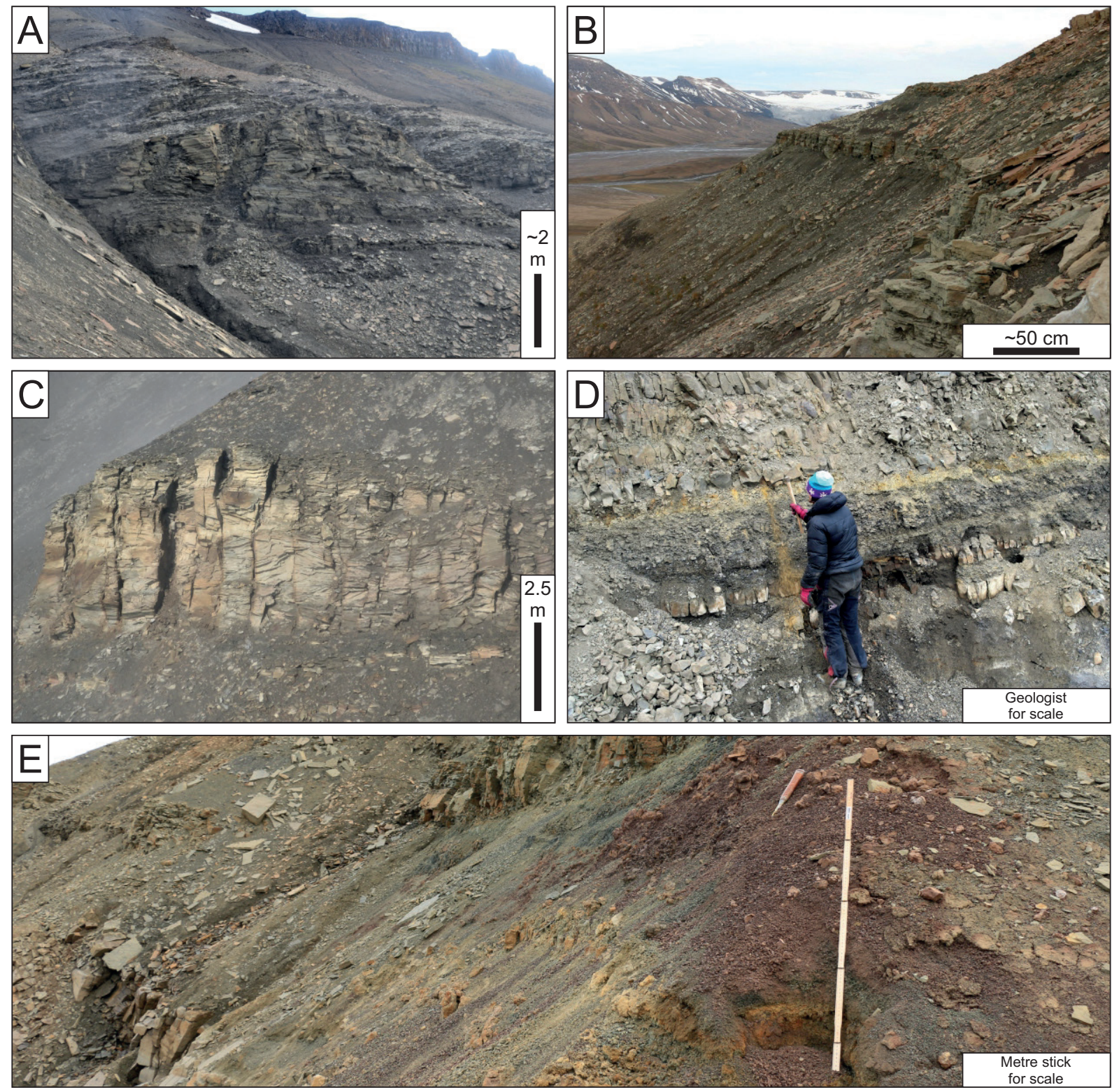

Figure 5. (A) Distributary mouth-bar deposits (FA 7) observed in the lower part of the mountainside at Svartnosa, Barentsøya (Figs. 1B, 6, 9). These mouth-bar deposits feature a soft-sediment deformed base (Facies D), overlain by trough and low-angle cross-stratification with wave ripples in the upper part (Facies $K, I, E$ ). This sandstone body is interpreted as representing a series of amalgamated distributary mouth-bar deposits. (B) Laterally extensive sandstone bench observed at Šmidtberget, Agardhbukta (Figs. 1B, 6), interpreted as forming barrier-bar deposits (FA 8). The sandstone is composed of low-angle cross-stratified sandstone (Facies I) with laterally restricted beds of plane-parallel laminated and trough cross-stratified sandstone (Facies, K) overlain by wave-rippled sandstones (Facies E). (C) Distributary channel deposits (FA 9) observed at Svartnosa on Barentsøya (Figs. 1B, 6, 9). These sandstones form a laterally extensive sheet, extending across the mountain, interpreted as amalgamated distributary channels composed of tabular and trough cross-stratified sandstone (Facies J, K). This facies association is commonly overlain by FA 10 or 11. (D) Flood-plain deposits (FA 10) exposed at Friedrichfjellet, Agardhbukta (Figs. 1B, 6), showing a well developed palaeosol horizon (Facies N), over heterolithic flood-plain deposits. (E) Interdistributary deposits (FA 11) observed at Klement'evfjellet in Agardhbukta (Figs. 1B, 6). Here, well developed beds of alternating green and red clay are observed with mudstone and heterolithic units (Facies A, B). These beds are interpreted as soil horizons (Facies $N$ ).

lateral continuity throughout the study area, forming sandstone 'benches' and are suggested to grade laterally into either distal or proximal facies associations (e.g., upper shoreface or mouth-bar deposits or floodplain deposits). Isolated distributary channel complexes are typically confined to the Isfjorden Member whilst amalgamated channel deposits are found in the middle part of the De Geerdalen Formation. The relatively modest dimensions characterising laterally restricted fluvial channel deposits could possibly be explained by frequent switching and abandonment on the delta plain (Reading \& Collinson, 1996). The amalgamated deposits may represent periods of relatively stable base level, thereby allowing the extensive lateral migration as, for example, observed at Svartnosa (Fig. 5A).

FA 10 - Floodplain 
Description: Floodplain deposits (Fig. 5D) are found extensively throughout the study area. The facies association is typically found in thin units overlying distributary channel deposits, or as thick and laterally extensive deposits in the upper part of the De Geerdalen Formation. These deposits are composed primarily of mudstones (Facies A) with thin, normal-graded beds of fine-grained sandstone with wave and current ripples (Facies E and F). Minor sandstone beds with tabular cross-stratification (Facies J) may be present. Coal, coaly shales and palaeosols (Facies M and N; Fig. 5D) are found both at the tops of distributary channels and extensively within floodplain deposits. Plant fragments and bioturbation in sandstone beds are common. Floodplain deposits typically range between two and twenty metres in thickness in the study area.

Interpretation: Distributary channels (FA 3) together with floodplains are the main areas of activity on the delta plain (Bhattacharya, 2006). Floodplains receive most of the sediments from distributary channels and the sediment load in most rivers contains as much as $85-95 \%$ mud (Schumm, 1972). Mud is primarily carried in suspension (Bhattacharya, 2006). Beds of mud on the floodplain may be interrupted by silt and sand sourced from levees and crevasse splays. During periods of flood, levees may breach and crevasses splays advance onto the delta plain, leading to deposition of silt and sand in lobes. Crevasse splays may form distinct layers of rippled sandstone and thin beds of siltstone that generally fine away from the source channel. Bioturbation is common. Floodplains are commonly exposed during low water level, leading to pedogenesis. In humid conditions, the floodplain sediments may stay wet and peat may accumulate, resulting in the formation of coal (Fig. 5D; Collinson, 1996).

\section{FA 11 - Interdistributary areas}

Description: Interdistributary areas (Fig. 5E) are recognised by less sand content in comparison to distributary areas and floodplain deposits, with a greater marine influence. They are dominated by normal-graded mudstone (Facies A), in places interrupted by thin coal and coal shales (Facies M), or alternating red and green palaeosols (Facies N). Some exposures interpreted as this facies association contain beds of wave-rippled, symmetrical rippled or plane parallel laminated sandstone (Facies E, F and H). Palaeosols (Facies N) are commonly found underlying coal or coal shales (Facies $\mathrm{M})$ and directly overlying mudstones (Facies $\mathrm{M}$,) or distributary channels. In some sections palaeosols are found dispersed within mudstones (Facies M). Coquina beds (Facies L) are also abundant in this FA forming laterally extensive and relatively thin, bioclastic beds with abundant bivalve and shell fragments.

Interpretation: Interdistributary areas are herein considered as standing bodies of water such as lagoons and lakes, as well as marshes and swamps. Facies successions are in general seen as quite thin, coarsening or fining-upward units (Bhattacharya, 2006). Coal and coal shales found in the De Geerdalen Formation are thin and appear impure, leading to the interpretation that they originate in the lower delta-plain setting, in saline marshes. Thin coal seams with a limited lateral continuity support the relatively dynamic and unstable paralic regime interpreted for the De Geerdalen Formation (Klausen \& Mørk, 2014; Rød et al., 2014; Paterson et al., 2016).

Coquina beds found in this FA could form due to very slow rates of deposition following a major avulsion, delta lobe or distributary switching, or eustatic sea-level rise, e.g., the 'Abandonment facies association' of Reading \& Collinson (1996). These conditions are common in interfluvial areas where limestone, coals or highly condensed horizons bioturbated by plants or animals are present (Reading \& Collinson, 1996). Abundant molluscs are found in interdistributary bay sediments in the modern Mississippi delta (Frazier, 1967).

Palaeosols indicate a time of subaerial exposure and only form if the sedimentation rate does not exceed the rate of pedogenesis (Kraus, 1999; Kraus \& Aslan, 1999). Palaeosols are an indicator of periods with little or no sedimentation and are the clearest indicators of an interdistributary regime. Palaeosols above distributary channel facies typically indicate channel abandonment.

In the upper part of the De Geerdalen Formation, red and green, nodular palaeosols (Fig. 5E) and caliche horizons are common. These differ from grey and yellow palaeosols, coals and coal-shales seen in in the remainder of the formation. This change is documented in stratigraphical terms by the Isfjorden Member (Pčelina, 1983; Mørk et al., 1999a; Haugen, 2016). Red nodular clays are interpreted as representing an unaltered, oxidised soil profile, whilst green and grey suggests an environment with reducing conditions (Haugen, 2016). The alternating presence of these beds is useful for gaining insight into environmental fluctuations at the time of deposition. In addition, as they represent extended periods of subaerial exposure (Webb, 1994) and non-deposition, these beds can thus also be considered as a minor hiatus (Kraus, 1999).

\section{Depositional environments}

Due to the paralic nature of the Upper Triassic in eastern Svalbard (Mørk et al., 1999a; Klausen \& Mørk, 2014; Lord et al., 2014a, b; Paterson \& Mangerud, 2015; Paterson et al., 2016; this study), individual facies associations are difficult to correlate laterally over wide areas. To overcome this problem and to ease regional correlation, the facies associations have been grouped into four gross depositional environments (DE). These are: DE 1 - open marine shelf and prodelta, DE 2 - shallow marine, DE 3 - delta front, DE 4 - delta plain. The method builds 


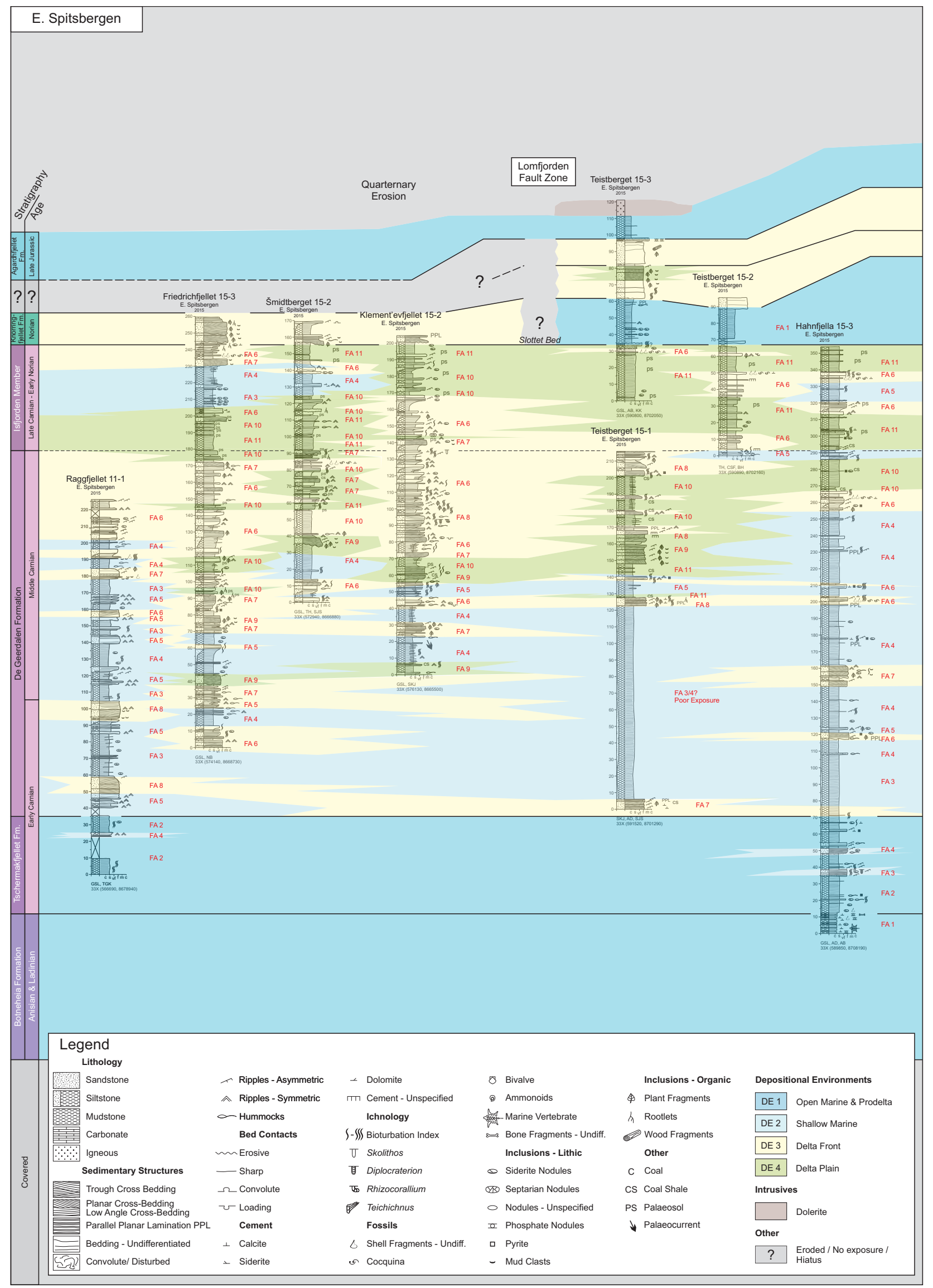

Figure 6. Log correlations for sections measured throughout eastern Spitsbergen, Barentsøya and Wilhelmøya. Positions of individual logs are marked on the locality map in Fig. 1B. Depositional environments are interpreted for various levels in the stratigraphy based upon the interpreted facies and facies associations. Units overlying and underlying the De Geerdalen Formation are also briefly interpreted. 


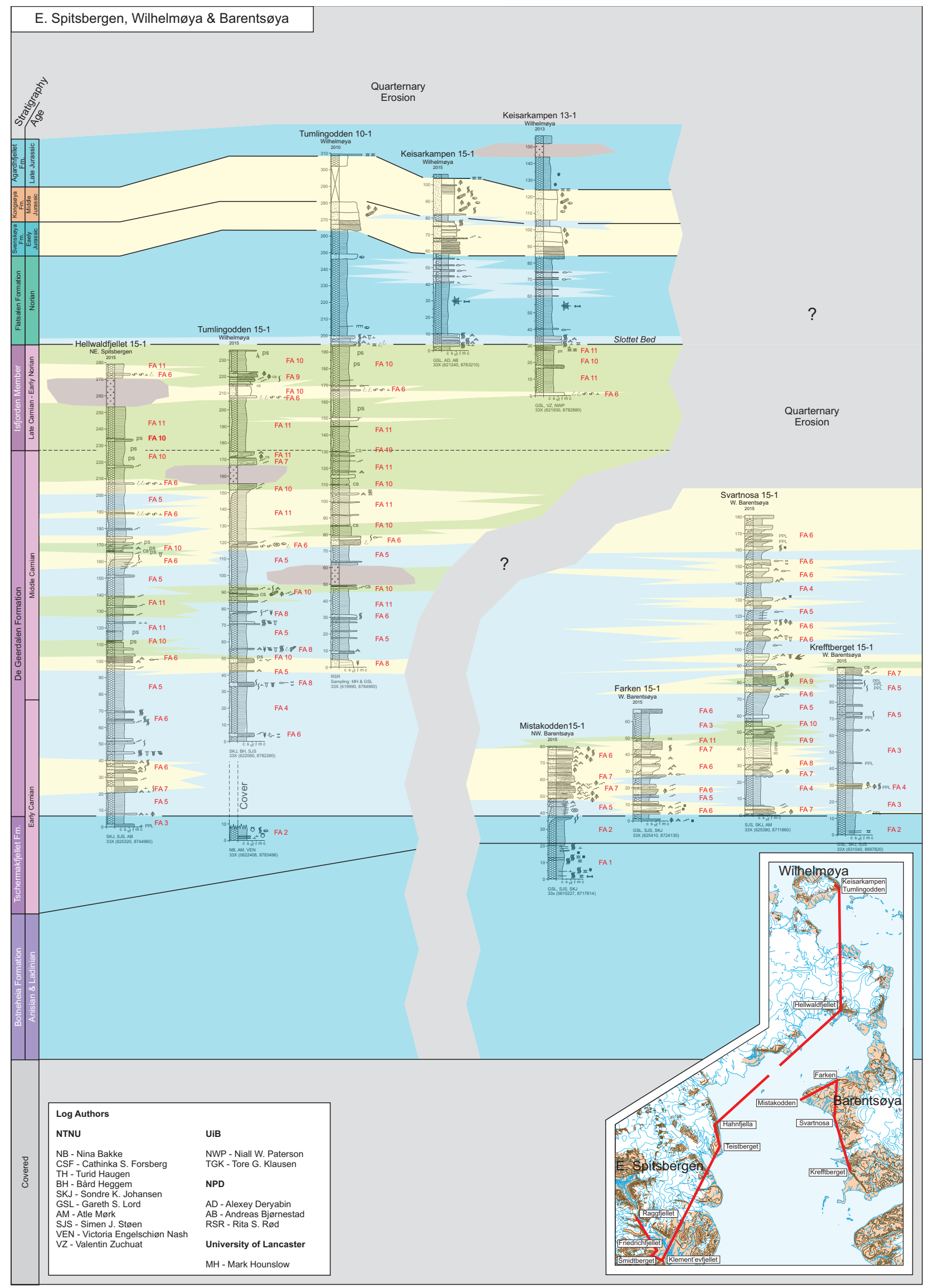


on the principles used by Rød et al. (2014) in Edgeøya and central Spitsbergen (Table 2; Fig. 6). Subdivision according to the gross depositional environment has been applied to the full length of sections and the following descriptions of depositional environments relate to those shown in the log correlation panel in Fig. 6.

A generalised, conceptual depositional model for the Botneheia, Tschermakfjellet and De Geerdalen formations is presented in Fig. 7 and is based on concepts from Bhattacharya \& Walker (1992), Reinson (1992), Howell et al. (2008), Glørstad-Clark et al. (2011) and Rød et al. (2014). The log from Hahnfjella (Figs. 1B, 2B, 6 ) is presented alongside as it shows a near complete succession of the De Geerdalen Formation, a complete succession of the Tschermakfjellet Formation and the upper part of the underlying Botneheia Formation.

Depositional environment 1 - open marine shelf \& prodelta

Description: Open marine shelf deposits (FA 1; Figs. $4 \mathrm{~A}, 7)$ are constrained to the Botneheia and Flatsalen formations overlying and underlying the Storfjorden Subgroup (Fig. 2A). The depositional environment consists almost exclusively of open marine shelf facies and organic rich shales (Fig. 7).

Prodeltaic shales of the Tschermakfjellet Formation (FA 2; Fig. 4B) are also included in this depositional environment as they represent the most distal portion of the deltaic deposits that make up the Storfjorden Subgroup. The upper part of the Tschermakfjellet Formation shows transitions to DE 2 with FA 3 and 4 (Table 2) being present at some localities where the Tschermakfjellet Formation is exposed (e.g., Raggfjellet and Hahnfjella, Fig. 1B).

Interpretation: This depositional environment represents a deep shelf basin, with pelagic sedimentation, occurring over an extended period of time (Mørk et al., 1982). The grey mudstones and siltstones of the Tschermakfjellet Formation represent the onset of a regressive deltaic system in the study area atop of the open marine Botneheia Formation.

\section{Depositional environment 2 - shallow marine}

Description: This depositional environment is characterised predominantly by shallow-marine facies within the De Geerdalen Formation or the very upper parts of the Tschermakfjellet Formation. FA 3 and 4 (Table 2; Fig. 4B, C) are common within this DE and appear as laterally continuous, upward-coarsening units that extend for several kilometres. Shallow-marine intervals within the De Geerdalen Formation generally form the bases of regressive parasequences (Fig. 5A, C) and mark repeated episodes of deltaic abandonments and shoreline retreats in an overall, long-term, regressive system. Parasequences are commonly composed of FA 3 and 4 (Table 2; Fig. 4C, D) with lower shoreface deposits of FA 5 (Table 2; Fig. 4E) in their lower part. These units grade upwards into DE 3, highlighting the regressive and shallowing trend.

Interpretation: This gross environment represents either the most proximal parts of the prodeltaic Tschermakfjellet Formation or marine incursions that are observed throughout the De Geerdalen Formation, predominantly in the lower parts of parasequences. The environment is easily recognised in the field as screeforming slopes between prominent sandstone benches. The bases of these units commonly mark the onset of flooding surfaces that mark the bounding surface for shallowing-upward parasequences.

\section{Depositional environment 3 - delta front}

Description: This environment consists of upper shoreface deposits (FA 6; Figs. 4F, 7), distributary mouthbar deposits (FA 7; Fig. 5A) and barrier-bar deposits (FA 8; Fig. 5B). The facies and facies associations within this environment are often laterally extensive and form prominent benches of sandstone, which represent the coarsest grained component of upward-shallowing parasequences seen throughout the study area.

Interpretation: This environment which is dominated by various sandstone facies is indicative of a delta-front environment. Sandstones within this environment often represent the coarsest part of upward-shallowing successions that form parasequences seen throughout the De Geerdalen Formation.

\section{Depositional environment 4 - delta plain}

Description: Facies associations assigned to this environment are typically fine-grained floodplain deposits and palaeosols (FA 10; Figs. 5D, E, 7). Sandstones are evident as distributary channel deposits (FA 9), or interpreted as overbank deposits, crevasse splays or bars (FA 10) within a distributive system on the delta top (Fig. 5). Intervals forming in this depositional environment are generally very thin. In the lower parts of the De Geerdalen Formation they are generally found to cap sandstone bodies. In the Isfjorden Member, deposits of DE 4 form extensive fine-grained deposits interspersed with palaeosols (FA 10). Interdistributary areas (FA 11; Fig. 5E), forming between distributary channel deposits, are also included within this DE.

Interpretation: The delta-plain environment has been confined to include facies on the delta plain that have been deposited outside the influence of marine processes as well as those forming in interdistributary areas that represent sedimentation in brackish waters (e.g., interdistributary bays or lagoonal settings). Units composed of facies that are assigned to this DE generally overlie facies and facies associations assigned to DE 3 and in many cases form the uppermost parts of shallowing upwards parasequences. Thicker deposits assigned to this DE are observed in the Isfjorden Member and are regarded as representing lagoon or lacustrine deposits 

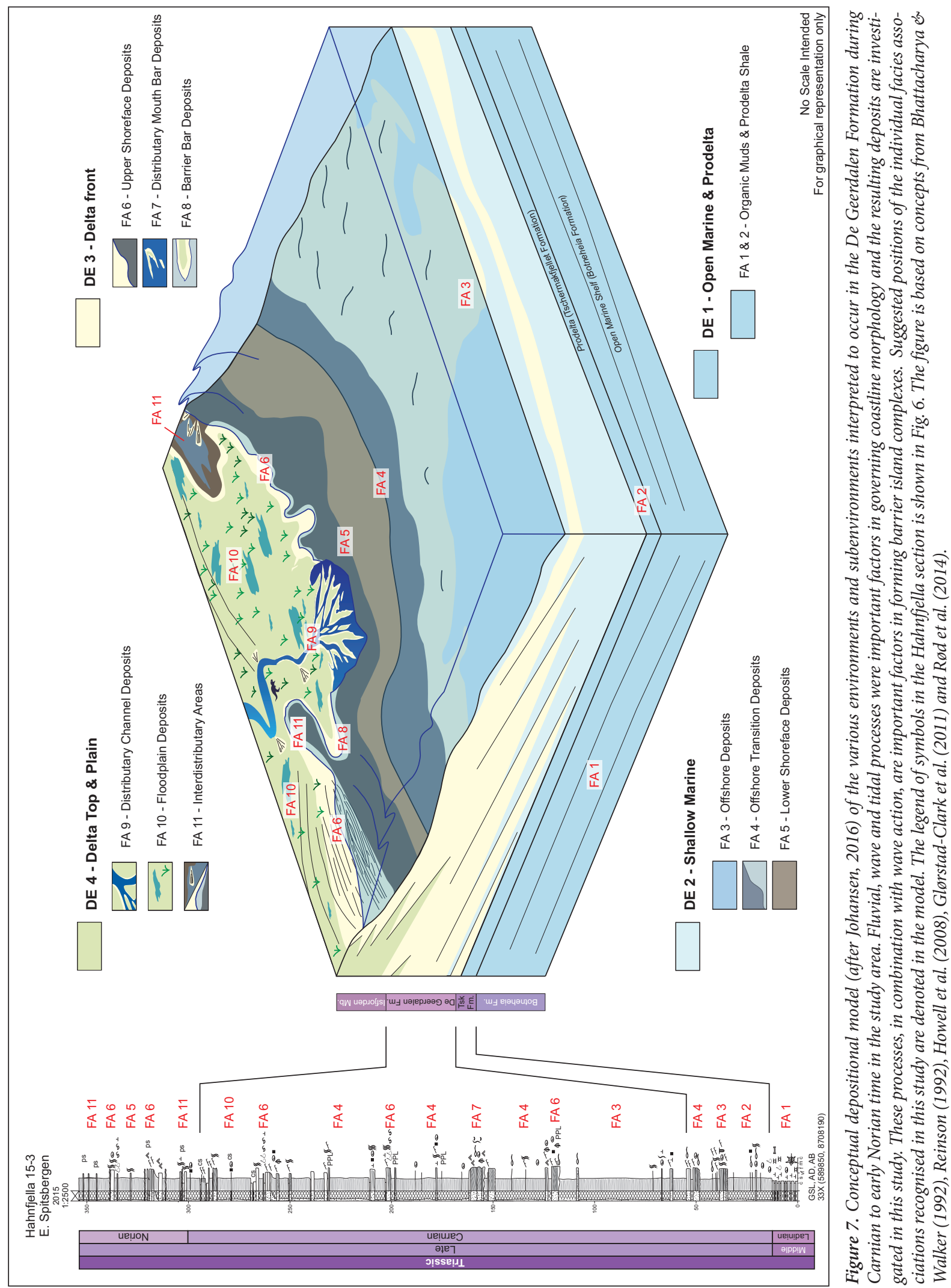
(Pčelina, 1983; Mørk et al., 1999a; Haugen, 2016). The DE in the Isfjorden Member suggests prolonged periods of deposition in a restricted environment. A fluctuating climate and water-table is proposed for this unit, due to the presence of extensive palaeosols (Fig. 5E; Haugen, 2016).

\section{Stratigraphic distribution and correlation of depositional environments}

The depositional environments and their respective facies associations are discussed in the context of three stratigraphic units (subdivision shown in Fig. 6): 1) a lower Carnian, 2) a middle Carnian, and 3) an upper Carnian to lower Norian unit. The lower and middle Carnian units are represented by the Tschermakfjellet Formation and the bulk of the De Geerdalen Formation. The upper Carnian to lower Norian unit is represented by the Isfjorden Member. The use of the gross depositional environments for correlation solves the highly complex problem of facies distributions throughout the Tschermakfjellet and De Geerdalen formations.

It should be noted that despite well constrained palynological dating for most of the lithostratigraphic units in the Triassic succession of Svalbard (e.g., Vigran et al., 2014; Paterson \& Mangerud, 2015; Paterson et al., 2016), the middle Carnian unit is poorly constrained and the present assignment should therefore be considered subjective. The middle Carnian age assignment is based entirely on indirect stratigraphic relationships between the middle Carnian unit, the underlying early Carnian Tschermakfjellet Formation and the overlying Isfjorden Member (late Carnian to early Norian).

\section{Lower Carnian}

Throughout the study area, prodeltaic shales (FA 2, Table 2) of the Tschermakfjellet Formation (Figs. 4B, 8) were deposited during earliest Carnian time, in advance of the delta-front and delta-top deposits that make up the De Geerdalen Formation. The unit consists of facies assigned to DE 1 throughout eastern Spitsbergen, with minor shallow-marine intervals (DE 2) being present (e.g., Raggfjellet and Hahnfjella, Fig. 1B).

The base of the De Geerdalen Formation is given as the first prominent sandstone above the Tschermakfjellet Formation. However, due to the widespread thickness variations in the Tschermakfjellet Formation as well as thickness variations in these basal sandstones, this definition is somewhat arbitrary. Throughout the study area, the first prominent sandstone generally represents lower or upper shoreface sandstones (FA 5 and FA6) or mouth-bar deposits (FA 7), displaying reworking by wave processes (Fig. 4F). These sandstone beds are often thin and laterally extensive, cemented either by calcite or siderite, and are generally considered to have been deposited in a delta-front environment. The lowermost sandstone exposures can be considered as the termination of an upward-shallowing transition, between the Tschermakfjellet and De Geerdalen formations.

On Barentsøya, the Svartnosa and Mistakodden sections (Figs. 1B, 6) feature thick units of sandstone interpreted as representing delta-front sandstones (DE 3) with upper shoreface, distributary mouth-bar and barrierbar deposits (FA 6,7 and 8) being the dominant facies associations recognised. The delta-front sandstone seen at Svartnosa (Fig. 9) forms a lenticular sandstone body that is $c .30 \mathrm{~m}$ in thickness and laterally extensive over hundreds of metres. The lenticular geometry and internal facies of this sandstone body suggest it represents a delta lobe, similar to that reported at Blanknuten on Edgeøya (Knarud, 1980; Rød et al., 2014). The sandstone body is subsequently overlain by FA 9 and 10, showing a transition to delta-plain deposits (DE 4), consisting of fine-grained floodplain and distributary channel deposits (FA 9, 10, Table 2). The remainder of the lower Carnian on Barentsøya is comprised of shallow-marine (DE 2) and delta-front (DE 3) deposits.

The lower Carnian throughout the eastern Spitsbergen and Wilhelmøya area is dominated by delta-front and shallow-marine deposits (DE 2 and 3; Fig. 6), as shown in the Hahnfjella (Fig. 8) and Hellwaldfjellet sections. On Wilhelmøya the basal beds of the Tumlingodden section (Fig. 6) at sea level contain the bivalve Halobia sp. which is an index fossil of the lower Carnian Tschermakfjellet Formation. Facies associations form upward-shallowing parasequences (in the order of $30-50 \mathrm{~m}$ in thickness) that typically show a coarsening-upward trend from fine-grained facies associations (FA 3, 4 and 5) to deltaic facies (FA 6, 7 and 8). This can be seen in the Raggfjellet section (Figs. 1A, 6) from c. $40 \mathrm{~m}$ to $100 \mathrm{~m}$. Here, two vertically stacked shallowing-upward parasequences, formed of shallow-marine and deltaic facies (DE 2 and 3), are evident (Fig. 6).

\section{Middle Carnian}

Well exposed and prominent upward-shallowing units dominate the middle Carnian part of the succession throughout the study area (Fig. 6). The units are well defined and coarsen upwards from silt to mediumgrained sandstones, forming parasequences of approximately 20-30 m thickness. The lower part of the middle Carnian is dominated by shallow-marine (DE 2) and delta-front (DE 3) environments typically composed of FAs 3, 4, 5, 6 and 7 (Table 2). Minor occurrences of delta-plain (DE 4) deposits are present as distributary channel deposits (FA 9), overlain by palaeosols and coal horizons, interpreted as representing floodplain deposits (FA 10), the most notable being observed at c. 20-50 $\mathrm{m}$ in the Friedrichfjellet section (Fig. 6). Here, a c. 30 $\mathrm{m}$-thick parasequence is exposed composed of offshore transition deposits (FA 4) and lower shoreface deposits (FA 7; Fig. 4D, E) grading into distributary channel deposits (FA 9). This parasequence is subsequently 

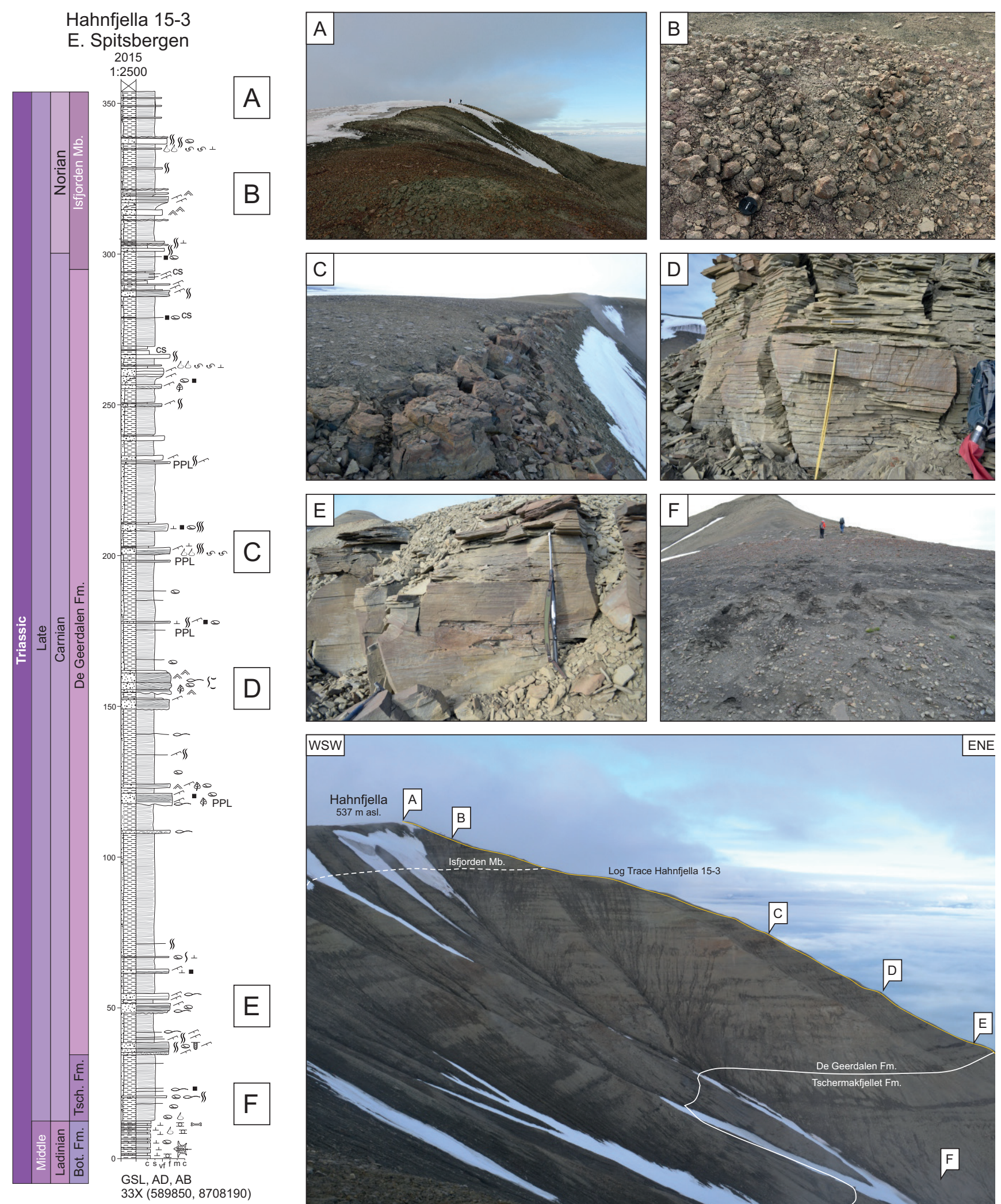

Figure 8. Sedimentological section and overview photo of Hahnfjella (Fig. 1B), eastern Spitsbergen, with accompanying photos (A-F) of prominent lithologies seen at this location. The overview photo shows the trace of the section measured in log Hahnfjella 15-3. (A) Green and red beds of the Isfjorden Member palaeosol horizons cap the mountain. (B) Detail photo showing the nodular nature of the red beds (lens cap for scale). (C) A thick and well exposed bed of fragmented shells (coquina bed) is well preserved due to cementation. (D) Low-angle trough cross-stratified sandstone with an erosive base observed in the lower part of the section. This sandstone is interpreted as representing a minor distributary channel. (E) Low-angle cross- and planar-stratified sandstone common to the De Geerdalen Formation; the beds are commonly cemented and weather red. (F) The prodelta shale of the Tschermakfjellet Formation is well exposed, as is the boundary to the Botneheia Formation (not shown). Siderite concretions (in places containing ammonoid imprints) are common. Legend to section in Fig. 6. 
overlain by fine-grained sediments interpreted as lower shoreface deposits, with a minor flooding surface at the base.

Similarly, between $50 \mathrm{~m}$ and $115 \mathrm{~m}$ in the Friedrichfjellet section (Fig. 6), a c. $65 \mathrm{~m}$-thick shallowing-upward succession from shallow-marine facies (FA 5) to delta-front and delta-plain facies can be observed. These relatively thick parasequence units can be seen throughout much of the remaining part of the middle Carnian, where delta-front and delta-plain facies interfinger with shallow-marine deposits throughout the study area. The De Geerdalen Formation is largely described as paralic (Klausen \& Mørk, 2014; Lord et al., 2014a, b; Rød et al., 2014; Paterson et al., 2016) and this is reflected in the highly variable lateral distribution of facies and depositional environments.

\section{Upper Carnian-Lower Norian}

The upper part of the De Geerdalen Formation throughout eastern Svalbard is defined by the Isfjorden Member (Figs. 2A, 6), deposited during the latest part of the Carnian and early Norian (Pčelina, 1983; Mørk et al., 1999a; Vigran et al., 2014; Haugen, 2016). In the field, the basal beds of the Isfjorden Member are difficult to identify at outcrop level, but distinct visual changes can be observed from scree in mountainsides. The presence of alternating, green and red, nodular palaeosols (Figs. $5 \mathrm{E}, 8$ ) is characteristic for the member (Facies N, FA 10 and 11) and such palaeosols are observed at most locations in eastern Spitsbergen and Wilhelmøya.

The most northern exposures of the Isfjorden Member are found on Wilhelmøya (Tumlingodden and Keisarkampen) and at Hellwaldfjellet (Figs. 1B, 6). Here, the member is dominated by siltstone, with thin sandstones and coquina beds in its lower part. The upper part consists of alternating green and red nodular clays, directly underlying the Wilhelmøya Subgroup. These alternating green and red beds are also apparent at Hahnfjella (Figs. 1B, 2B, 6, 8), where they are excellently exposed and dominate the upper exposures of the mountainside.

Alternating red and green palaeosol horizons are also observed in the Agardhbukta areas (e.g., Klement'evfjellet, Šmidtberget and Friedrichfjellet, see Figs. 1B, 6). On Wilhelmøya and at Teistberget, the Norian Flatsalen Formation directly overlies beds of palaeosol (Fig. 6). However, in the Agardhbukta area palaeosol horizons are overlain by an upper interval of marine shale (Fig. 4C), siderite beds and shoreface sandstones, uncommon for this part of the succession. This suggests that there was a transgression of the delta plain leading to a ravinement surface and eventually flooding covering the entire area with marine water and depositing FA 3. During the following regression, shallow-marine deposits (FA 4) were laid down. The coarsening-upward trend within the parasequences reflects progradation of the shallow-marine environments, and the thickness of the parasequence reflects the water depth at the time of progradation. Palynological dating of selected samples from Friedrichfjellet indicate a Carnian age for this marine interval. The overlying sandstone $(240 \mathrm{~m}$ on the Friedrichfjellet log, Fig. 6) includes Norian palynomorphs suggesting that they belong of the Flatsalen or Knorringfjellet formations in the Wilhelmøya Subgroup (Niall Paterson, pers. comm., 2016).

\section{Discussion}

\section{Palaeogeographic development}

A subdivision into lower Carnian, middle Carnian and upper Carnian-Norian units means that it is possible to better infer the palaeogeography for the study area. The palaeogeography for these three intervals is discussed and presented in the series of palaeogeographic maps in Fig. 10. The maps are based on tentative correlations and are only meant to show one of many tenable solutions.

Lower Carnian: The lower Carnian unit is typically dominated by prodeltaic deposits of the Tschermakfjellet Formation throughout the study area. The lower Carnian part to the overlying De Geerdalen Formation is predominantly composed of shallow marine and shoreface deposits in the eastern Spitsbergen and Wilhelmøya areas (Fig. 10). Only minor fluvial influence and delta-front advances are interpreted, particularly in the uppermost part of a shallowing-upward parasequence at Friedrichfjellet. Agewise, this unit represents the onset of the middle Carnian in the area.

On Barentsøya, however, the lower Carnian at Svartnosa (Figs. 1B, 10) shows evidence for a deltaic advance in the form of an extensive lenticular sandstone body (Fig. 9), composed of delta-front and delta-plain sediments, interpreted as representing a delta lobe which likely prograded towards the west. In addition, a thick sandstone unit is observed at Mistakodden, whilst Farken is composed of predominantly deltaic facies (FA 7). The southern part of Barentsøya is considered as representing a shallow-marine to delta-front environment following interpretation of the succession at Krefftberget (Fig. 1B).

Middle Carnian: In contrast to the lower Carnian, the middle Carnian part of the succession shows major regressive deltaic advances, with distributive facies (FA7 and 9) becoming more common (Figs. 6, 10), as do delta-top sediments (Fig. 6). Interdistributary bay areas, or areas of marine incursion due to avulsion of the fluvial distributary systems, are also evident with minor intervals of shallow-marine facies being present in this unit, notably on Barentsøya.

The Agardhbukta area (Fig. 1B) is interpreted to have 

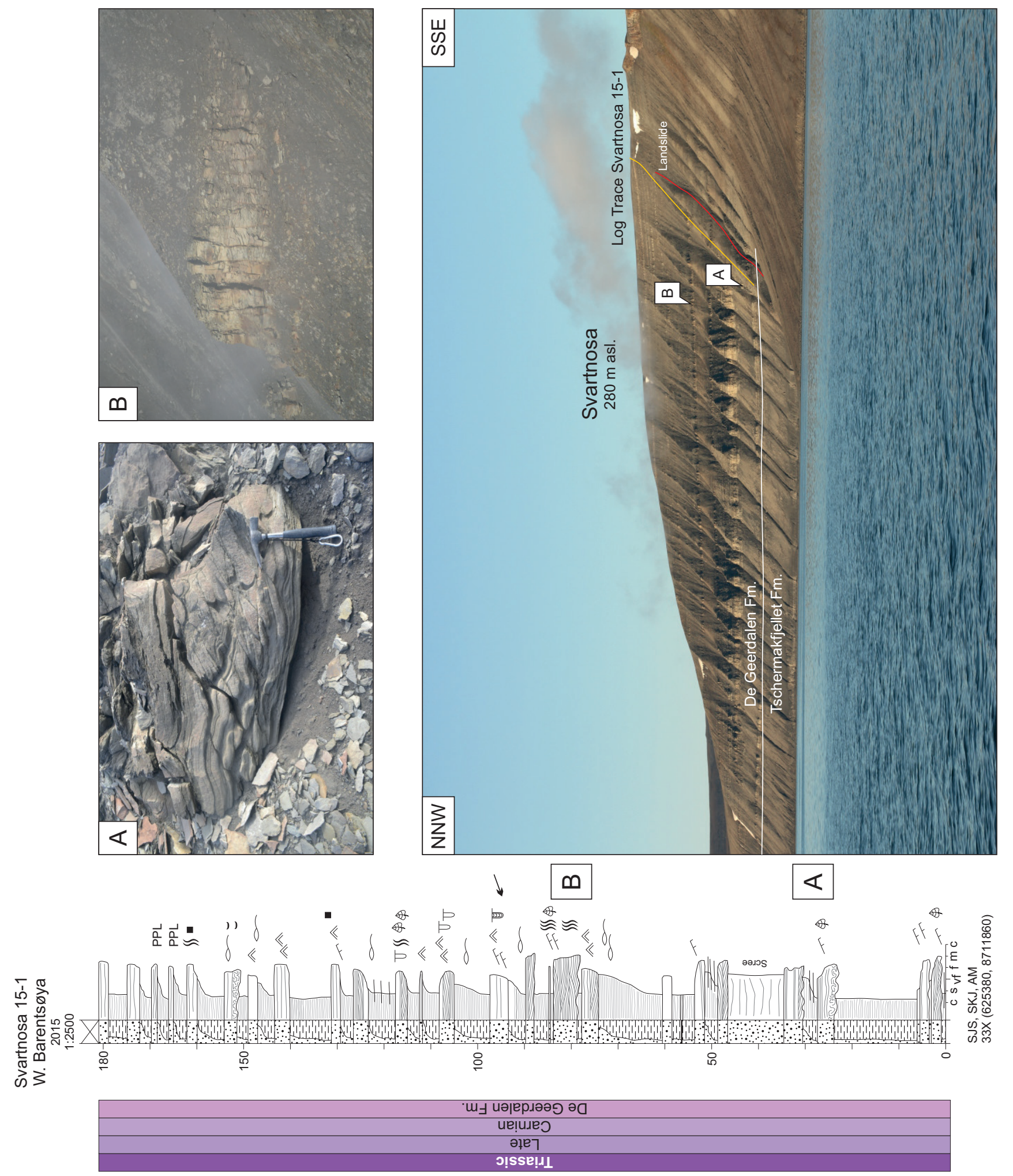

Figure 9. Sedimentological section and overview photo of Svartnosa (Fig. 1B), Barentsøya, with accompanying photos (A-B). The log trace is shown by the yellow line in the overview photo. (A) Soft-sediment deformed bedding, observed in the lower sandstone beds of the De Geerdalen Formation, interpreted as forming the base of an amalgamated distributary mouth-bar unit. (B) Fluvial distributary channel facies observed in the middle part of the mountain, consisting of trough cross-stratified, medium-grained sandstone forming a laterally extensive sandstone body with amalgamated fluvial distributary channel facies. Legend to section in Fig. 6. 

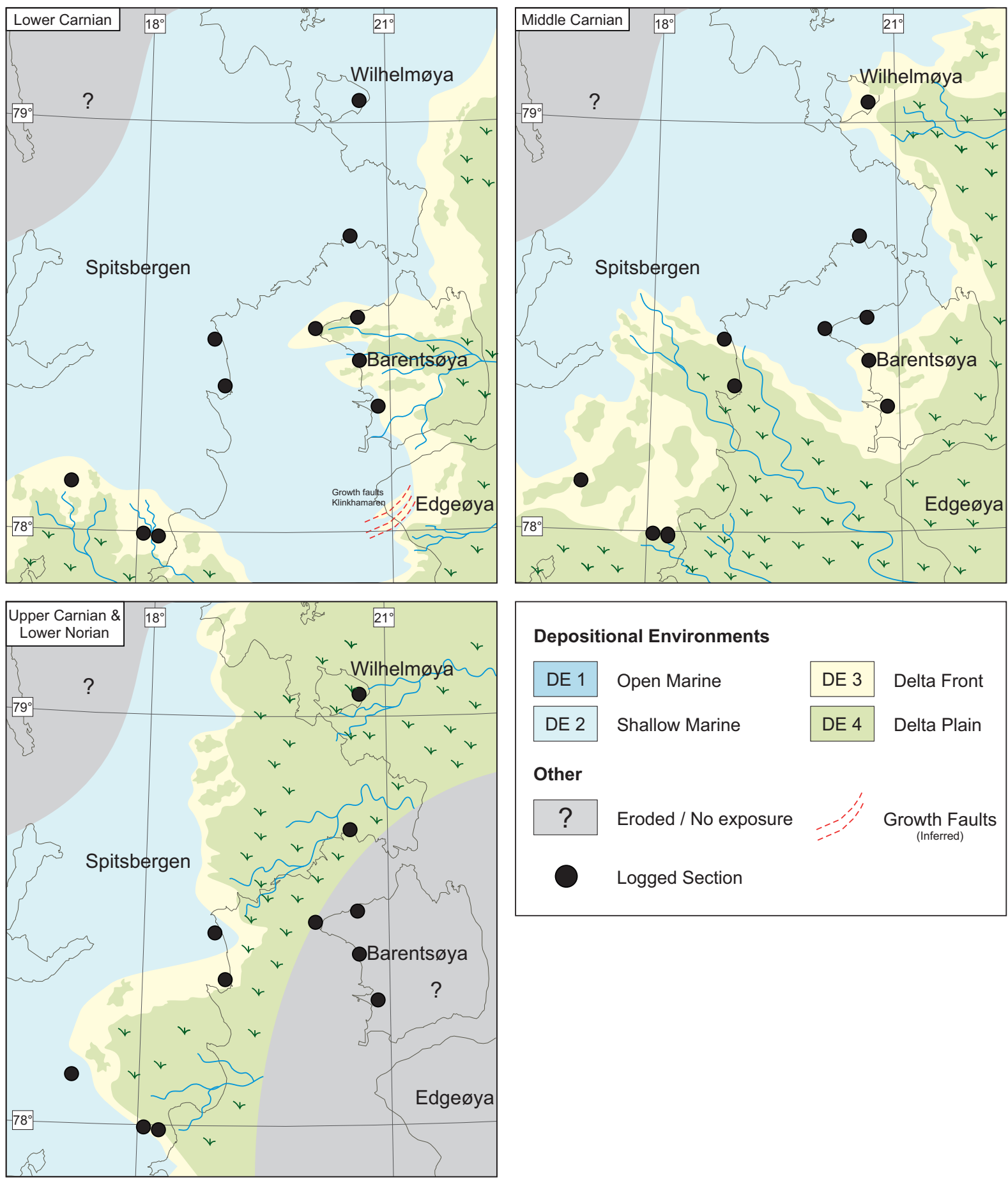

Figure 10. Conceptual palaeogeographic representations of the study area, showing a suggested palaeogeographical setting for the lower, middle and upper Carnian to lower Norian. Interpretations are based on outcrop data and log correlations (Fig. 6). The lower Carnian is represented by the deposition of prodeltaic shales (DE 2) and prominent delta-lobe advances (DE 3 and 4; Fig. 6) in the Svartnosa and Agardhbukta areas (see Figs. 1B, 6). The middle Carnian is dominated by the development of a paralic delta plain, with widespread delta-front (DE 3) and delta-plain deposits (DE 4). The late Carnian-early Norian (Isfjorden Member) suggests that a lagoonal environment was dominant, with only minor fluvial deposition occurring at this time. Finer-grained sediments are more common and parasequences become thinner. Palaeosols dominate the upper part of the Isfjorden Member during this time. 
been located in a paralic to near-shore setting dominated by delta-front and shallow-marine facies (Figs. 6, 10). Delta-plain environments are also evident with distributary channel deposits being present in the areas of Friedrichfjellet, Šmidtberget and Klement'evfjellet (Fig. 6). The localities of Teistberget and Hahnfjella are suggested as representing a terminal distributary system with limited lateral extent, due to the presence of deltaic and marine environments at Hahnfjella, at the same interval as fluvial facies are observed at Teistberget.

Sections on Wilhelmøya (Fig. 1B) display a paralic succession in the middle Carnian, with units of shallowmarine, delta-front and delta-plain deposits occurring locally. This area is interpreted as being a channellised minor delta-lobe system. Palaeosols, coal and coaly shales are typically found capping distributary channel and mouth-bar deposits within the middle Carnian part of the De Geerdalen Formation (Fig. 6). This may suggest an extended period of subaerial exposure, allowing for mature soil profile development (see Haugen, 2016), whilst coal and coal shale units indicate a humid climate and a waterlogged environment with rapid depletion of oxygen (Retallack, 1991). Shell beds seen in the middle Carnian on Wilhelmøya are typically isolated within either marine facies (FA 3 or 4) or interdistributary facies (FA 11) and may represent shell banks in a shallowmarine or lagoon setting.

The middle Carnian unit on Barentsøya is only observed at Svartnosa (Figs. 6, 9). The lower part of the middle Carnian is marked by a well-defined sandstone bench composed of FA 9; distributary channel deposits (Fig. 5C). This is potentially correlative to a sandstone bench observed in the upper part of the section at Farken (Fig. 6), which is interpreted as distributary mouth-bar deposits (FA 7) overlain by coal shale. The remainder of the middle Carnian succession on Barentsøya typically shows shallow-marine or delta-front facies (FA 4 and 5) suggesting the presence of an interdistributary lobe bay area; no continental deposits (palaeosols, coals or coal shales) have been observed. This suggests that a marine transgression took place in the Barentsøya area at this time. In contrast, a delta-lobe advance is interpreted to have taken place in the eastern Spitsbergen area (Fig. 10).

Upper Carnian and lower Norian: In the upper Carnian and lower Norian unit, facies typical of the Isfjorden Member became widespread throughout Spitsbergen and Wilhelmøya (Figs. 2A, 6, 10). Facies variability within the Isfjorden Member is relatively discrete, with thick intervals of delta-plain deposits interspersed with only thin units of shoreface deposits (Fig. 6). Limited fluvial distributary facies are observed and where present are generally thin, laterally inextensive beds within floodplain deposits. In the Agardhbukta area, a marine incursion is observed in the mountains of Friedrichfjellet and Klement'evfjellet. Facies are similar to those reported in central Spitsbergen by Mørk et al. (1982) and Rød et al.
(2014). The upper part of the member is likely missing from the well exposed type-section at Storfjellet (Knarud, 1980). Towards the west the upper Carnian is inferred as being predominantly shallow marine, with offshore and tidal deposits dominating (Fig. 10; Knutsen, 2013; Husteli et al., 2014; Olaussen et al., 2015).

The upper Carnian and lower Norian succession in the study area is interpreted as representing an extensive delta plain (Fig. 10) dominated by lagoonal and lacustrine environments. The paralic systems that characterise the lower and middle Carnian succession throughout the study area appeared to have stabilised during late Carnian to early Norian times. The extensive delta plain with well developed palaeosols seen in this part of the succession indicate a more physically stable environment in comparison with the dynamic fluviodeltaic environment seen in the underlying lower and middle Carnian units.

\section{Regional comparison}

This study provides important infill to the preliminary studies conducted throughout Svalbard by Knarud (1980), as presented in Mørk et al. (1982). It further builds on the early sedimentological studies in the region by Lock et al. (1978) from Barentsøya and Edgeøya, Rød et al. (2014) from Edgeøya and central Spitsbergen and work on Hopen (Klausen \& Mørk, 2014; Lord et al., 2014a, b).

Field studies, supported by palynology (Niall Paterson, pers. comm., 2015), show that late Carnian sedimentary rocks are not present on Edgeøya and we interpret this to mean that Cenozoic uplift and Quaternary erosion has removed this part of the succession. Localities visited throughout this study typically feature the middle and upper part of the De Geerdalen Formation, with the Tschermakfjellet Formation and lower part of the De Geerdalen Formation being poorly exposed, due to scree cover.

On Edgeøya, the lower part of the Upper Triassic succession is composed of prodelta shales overlain by delta-front deposits and lagoonal to delta plain deposits in the upper part of exposed sections (Rød et al., 2014). Growth faulting is observed along the western side of the island (Figs. 3A, 10; Edwards, 1976; Anell et al., 2013; Osmundsen et al., 2014; Rød et al., 2014). The Carnian succession on Hopen is largely composed of fluvial deltaplain sediments with subordinate marine-influenced deposits (Klausen \& Mørk, 2014; Lord et al., 2014a, b) and is late Carnian in age (Paterson \& Mangerud, 2015; Patterson et al., 2016).

The Upper Triassic succession thins considerably throughout Svalbard, from southeast to northwest. In the southeast at Hopen, the 7626/5-1 well ('Hopen 
2', see Mørk et al., 2013; Anell et al., 2014a; Lord et al., 2014a) shows the Tschermakfjellet and De Geerdalen formations to be some $1100 \mathrm{~m}$ in thickness, which is thicker than initially reported by Lord et al. (2014a). The De Geerdalen Formation on Wilhelmøya is complete and is minimum $350-400 \mathrm{~m}$ in thickness (the lower part was not logged in this study due to scree cover); as the Tschermakfjellet Formation is present at sea level.

Below sea level at Hopen, gamma-ray logs from the 7626/5-1 well indicate that the De Geerdalen Formation likely has a similar grain-size trend as in sections elsewhere, with a high sand content and multiple coarsening-upward parasequences. This indicates similar depositional environments as those seen elsewhere in eastern Svalbard and offshore in the Sentralbanken High area (Lundschien et al., 2014).

Throughout central Spitsbergen, the De Geerdalen and Tschermakfjellet formations together are approximately $300 \mathrm{~m}$ in thickness (Vigran et al., 2014), whilst in the Barents Sea, offshore from Svalbard, the units are up to $1400 \mathrm{~m}$ in thickness (Mørk et al., 1999a; Lundschien et al., 2014). Anell et al. (2014a, b) relate this thinning to the progression of the Carnian deltaic system onto the Svalbard Platform (Dallmann et al., 2015), where lack of accommodation space has resulted in a shallowing of the basin and a rapid advance of the delta (Riis et al., 2008; Anell et al., 2014b).

If true, this mechanism explains the variable facies distributions seen throughout the study area. Lenticular sandstone bodies, as seen at Svartnosa on Barentsøya (Fig. 9) and at Blanknuten on Edgeøya (Rød et al., 2014), are not seen farther west in Spitsbergen. Instead, thin, laterally continuous, distributary channel, mouth-bar or shoreface deposits are present in these areas. This is also interpreted by Rød et al. (2014) to be a result of lower accommodation space to the west (Fig. 10). Laterally extensive sandstones are typically composed of distributary channel deposits in the present study area, whilst in central Spitsbergen laterally extensive shoreface deposits dominate (Rød et al., 2014).

The middle Carnian succession seen in eastern Spitsbergen is likely the time equivalent and distal component to the lower parts of the exposed De Geerdalen Formation on Hopen. On the island of Hopen, the lower part of the De Geerdalen Formation has been interpreted as representing delta-plain deposition close to an extensive, fern-dominated coastal mire (Paterson et al., 2016) (the presence of fern fossils is documented by Launis et al., 2014), with fluvial trunk and distributary channels (Klausen \& Mørk, 2014; Lord et al., 2014b). Paterson et al. (2016) have suggested that wet, humid conditions prevailed at this time, allowing for the accumulation of organic material and subsequent coal formation. Lord et al. (2014b) noted the presence of large tree remains. Whilst these may have been derived from much farther upstream, their presence suggests a well vegetated landscape, also indicated by the large volume of plant material seen in sandstone beds throughout the study area.

Similarly, Enga (2015) has documented the presence of palaeosols, coaly shale and coal horizons on Edgeøya, forming on top of delta-front and fluvial sandstones, or within fine-grained deposits in mud-dominated interdistributary or delta-plain settings. These palaeosols, which formed in delta-front and delta-plain settings, can be viewed as abandonment surfaces, marking a period of non-deposition after termination of sediment supply (Enga, 2015). Furthermore, in situ tree remains are present at a similar level in the stratigraphy at Blanknuten on Edgeøya (Enga, 2015).

The overall paralic setting seen elsewhere in Svalbard, with laterally discontinuous belts, suggests that the middle Carnian succession in the study area was deposited on a low-angle, delta plain (Knarud, 1980), with distributary channels bringing sediment to the delta shoreline where they were prone to wave reworking. The abandonment of delta lobes and fluvial systems resulted in local subaerial unconformities. Here, well developed palaeosols (Fig. 5D) formed above extensive sandstone bodies prior to being transgressed, as shown by a marine facies directly overlying palaeosols in the study area.

Additionally, the Isfjorden Member is laterally extensive throughout eastern Spitsbergen and on Wilhelmøya, where the alternating red and green palaeosols are seen to be directly overlain by the Slottet Bed, at the base of the Wilhelmøya Subgroup. Lord et al. (2014a) hypothesised that this part of the stratigraphy on Wilhelmøya may be the Hopen Member; however, this is not the case, and thus the Isfjorden Member has been extended to this area (Haugen, 2016) on the stratigraphic chart in Fig. 2A. The lateral extent of these two units offshore in the northern part of the Barents Sea is at present unknown.

The alternating red and green palaeosols of the Isfjorden Member (Figs. 5E, 8) are vastly different from those seen in the lower and middle Carnian parts of the De Geerdalen Formation throughout Svalbard, where they are characterised by yellow/grey clay with thin coal and coal shale (Fig. 5D). This may suggest either; (1) a climatic shift occurring during the late Carnian to early Norian, where palaeosols indicating a humid environment are replaced by those more indicative of an arid environment, or (2) a significant change in drainage pattern has resulted in a different type of pedogenesis (Haugen, 2016).

In southeastern Svalbard, the correlative Hopen Member features no palaeosols (Lord et al., 2014a), whilst the underlying De Geerdalen Formation displays thin, yet well developed coal beds and rootlets (Klausen \& Mørk, 2014; Lord et al., 2014b). Studies of plant fragments and 
remains from the De Geerdalen Formation on Hopen show a dominance of ferns and conifer flora (Launis et al., 2014), suggesting a more temperate environment for the De Geerdalen Formation. This is also supported by palynofacies and palaeogeography studies from Hopen (Paterson \& Mangerud, 2015; Paterson et al., 2016).

\section{Summary and conclusions}

In eastern Svalbard, the De Geerdalen Formation consists of multiple, discrete or indiscrete, upwardcoarsening units, interpreted as parasequences formed as a result of the progradation of a large, fluvial dominated delta system. The overall depositional environment for the De Geerdalen Formation can be considered as paralic, with deposition of sediments occurring in three key environments; delta plain, delta front and shallow marine.

Due to the low progradation angle of this system, these environments are easily influenced by changes in the delta or sea-level, with the high level of lateral variability of facies observed in the study area reflecting this. We address the depositional environments seen in the De Geerdalen Formation with a three-fold subdivision of the Upper Triassic succession into; (1) a lower Carnian unit consisting of shallow-marine to shoreface deposition; (2) a middle Carnian unit dominated by delta-front and delta-top deposits; and an upper part, (3) a late Carnian to early Norian unit, consisting of delta-plain deposits.

Acknowledgements. The authors wish to acknowledge the NPD for their support and funding, allowing for ship support during the later stages of fieldwork. We thank the Svalbard Science Forum for providing funding through the Arctic Field Grant and Det Norske Oljeselskap (now Aker BP) for additional funding. Cairn Energy (Capricorn Norway) is kindly thanked for providing transport and logistical support during field deployment. Special thanks are extended to the students of the East Svalbard Triassic Research Group at NTNU for excellent research efforts in the field; Turid Haugen, Cathinka Schaanning Forsberg, Bård Heggem, Nina Bakke and Victoria Engelschiøn Nash. In addition, thanks are extended to the geologists from NPD for their collaboration and support in the field; Bjørn Anders Lundschien, Andreas Bjørnestad, Alexey Deryabin and Katrine Karlsen. Referees Sten-Andreas Grundvåg and Morten Ahlborn are kindly thanked for their in depth reviews, that have greatly improved the quality and clarity of the manuscript.

\section{References}

Anell, I., Braathen, A., Olaussen, S. \& Osmundsen, P.T. 2013: Evidence of faulting contradicts quiescent northern Barents Shelf during the Triassic. First Break 31, 67-76. https://doi.org/10.3997/1365-2397.2013017.

Anell, I.M., Braathen, A. \& Olaussen, S. 2014a: The Triassic - Early Jurassic of the northern Barents Shelf: a regional understanding of the Longyearbyen $\mathrm{CO}_{2}$ reservoir. Norwegian Journal of Geology 94, 83-98.
Anell, I., Midtkandal, I. \& Braathen, A. 2014b: Trajectory analysis and inferences on geometric relationships of an Early Triassic prograding clinoform succession on the northern Barents Shelf. Marine and Petroleum Geology 54, 167-179. https://doi.org/10.1016/j.marpetgeo.2014.03.005.

Bhattacharya, J.P. 2006: Deltas. In Posamentier, H.W. \& Walker, R.G. (eds.): Facies models revisited, Society for Sedimentary Geology Special Publication 84, pp. 237-292.

https://doi.org/10.2110/pec.06.84.0237.

Bhattacharya, J.P. \& Giosan, L. 2003: Wave-influenced deltas: Geomorphological implications for facies reconstruction. Sedimentology 50, 187-210.

https://doi.org/10.1046/j.1365-3091.2003.00545.x.

Bhattacharya, J.P. \& MacEachern, J.A. 2009: Hyperpycnal rivers and prodeltaic shelves in the Cretaceous seaway of North America. Journal of Sedimentary Research 79, 184-209. https://doi.org/10.2110/jsr.2009.026.

Bhattacharya, J.P. \& Walker, R.G. 1992: Deltas. In Walker, R.G. \& James, N.P. (eds.): Facies Models: Response to Sea Level Change, Geological Association of Canada, pp. 157-177.

Boggs, S., Jr. 2009: Petrology of sedimentary rocks, Second edition. Cambridge University Press, Cambridge. 600 pp.

Boggs, S., Jr. 2011: Principles of sedimentology and stratigraphy, Fifth Edition. Pearson Prentice Hall, Upper Saddle River, New Jersey, 585 pp.

Buchan, S.H., Challinor, A., Harland, W.B. \& Parker, J.R. 1965: The Triassic stratigraphy of Svalbard. Norsk Polarinstitutt Skrifter 135, $94 \mathrm{pp}$.

Bue, E.P. \& Andresen, A. 2013: Constraining depositional models in the Barents Sea region using detrital zircon $\mathrm{U}-\mathrm{Pb}$ data from Mesozoic sediments in Svalbard. Geological Society of London Special Publication 386, 261-279.

Clifton, H.E. 2006: A re-examination of facies models for clastic shorelines. In Posamentier, H.W. \& Walker, R.G. (eds.): Facies Models Revisited, Society for Sedimentary Geology Special Publication 84, pp. 293-338.

Collinson, J.D. 1996: Chapter 3 - Alluvial sediments. In Reading, H.G. (ed.): Sedimentary environments: processes, facies and stratigraphy, Third Edition, Blackwell Science, Oxford, pp. 37-82.

Collinson, J.D., Mountney, N. \& Thompson, D.B. 2006: Sedimentary structures, Third Edition. Terra Publishing, London, $304 \mathrm{pp}$.

Corfu, F., Polteau, S., Planke, S., Faleide, J.I., Svensen, H., Zayoncheck, A. \& Stolbov, N. 2013: U-Pb geochronology of Cretaceous magmatism on Svalbard and Franz Josef Land, Barents Sea large igneous province. Geological Magazine 150, 1127-1135. https://doi.org/10.1017/S0016756813000162.

Dallmann, W.K. \& Elvevold, S. 2015: Chapter 7 - Bedrock Geology. In Dallmann, W.K. (ed.): Geoscience Atlas of Svalbard, Report Series 148, Norsk Polarinstitutt, Tromsø, pp. 133-174.

Dallmann, W.K., Elvevold, S., Majka, J. \& Piepjohn, K. 2015: Chapter 8 - Tectonics and tectonothermal events. In Dallmann, W.K. (ed.): Geoscience Atlas of Svalbard, Report Series 148, Norsk Polarinstitutt, Tromsø, pp. 175-224.

Dashtgard, S.E., MacEachern, J.A., Frey, S.E. \& Gingras, M.K. 2012: Tidal effects on the shoreface: Towards a conceptual framework. Sedimentary Geology 279, 42-61. https://doi.org/10.1016/j.sedgeo.2010.09.006.

Davis, R.A. 2012: Tidal signatures and their preservation potential in stratigraphic sequences. In Davis R.A \& Dalrymple, R.W. (eds.): Principles of tidal sedimentology, Springer Netherlands, Dordrecht , pp. 35-55. https://doi.org/10.1007/978-94-007-0123-6_3.

Dumas, S. \& Arnott, R.W.C. 2006: Origin of hummocky and swaley cross-stratification - the controlling influence of unidirectional current strength and aggradation rate. Geology 34, 1073-1076. https://doi.org/10.1130/G22930A.1.

Edwards, M.B. 1976: Growth faults in Upper Triassic deltaic sediments, Svalbard. The American Association of Petroleum Geologists Bulletin $60,341-355$. 
Eide, C.H., Klausen, T.G., Katkov, D., Suslova, A.A. \& HellandHansen, W. in press: Linking an Early Triassic delta to antecedent topography: source-to-sink study of the southwestern Barents Sea margin. Geological Society of America Bulletin.

Eiken, O. 1985: Seismic mapping of the post-Caledonian strata in Svalbard. Polar Research 3, 167-176. https://doi.org/10.1111/j.1751-8369.1985.tb00505.x.

Elvevold, S., Dallman, W.K. \& Bloomeier, D. 2007: The Geology of Svalbard. Norwegian Polar Institute, Tromsø, $38 \mathrm{pp}$.

Enga, J. 2015: Paleosols in the Triassic De Geerdalen and Snadd formations. MSc thesis, Norwegian University of Science and Technology, Trondheim, $127 \mathrm{pp}$.

Fleming, E.J., Flowerdew, M.J., Smyth, H.R., Scott, R.A., Morton, A.C., Omma, J.E., Frei, D. \& Whitehouse, M.J. 2016: Provenance of Triassic sandstones on the southwest Barents Shelf and the implication for sediment dispersal patterns in northwest Pangaea. Marine and Petroleum Geology 78, 516-535. https://doi.org/10.1016/j.marpetgeo.2016.10.005.

Flood, B., Nagy, J. \& Winsnes, T.S. 1971a: The Triassic succession of Barentsøya, Edgeøya and Hopen (Svalbard). Norsk Polarinstitutt Meddeler Nr. 100, 28 pp.

Flood, B., Nagy, J. \& Winsnes, T.S. 1971b: Geological map of Svalbard, sheet 1G, Spitsbergen southern part, scale 1:500,000, Norsk Polarinstitutt Skrifter $154 \mathrm{~A}$. (With short description).

Frazier D.E. 1967: Recent deltaic deposits of the Mississippi delta: their development and chronology. Gulf Coast Association of Geological Societies Transactions 17, 287-315.

Glørstad-Clark, E., Faleide, J.I., Lundschien, B.A. \& Nystuen, J.P. 2010: Triassic seismic sequence stratigraphy and paleogeography of the western Barents Sea area. Marine and Petroleum Geology 27, 14481475. https://doi.org/10.1016/j.marpetgeo.2010.02.008.

Glørstad-Clark, E., Birkeland, E., Nystuen, J., Faleide, J.I. \& Midtkandal, I. 2011: Triassic platform-margin deltas in the western Barents Sea. Marine and Petroleum Geology 28, 1294-1314.

Harstad, T. 2016: Sandstone Provenance of the De Geerdalen Formation, Svalbard - Emphasis on Petrography and Chromium Spinel Compositions. MSc thesis, Norwegian University of Science and Technology, Trondheim, $98 \mathrm{pp}$.

Haugen, T. 2016: A Sedimentological Study of the De Geerdalen Formation with Focus on the Isfjorden Member and Palaeosols. MSc thesis, Norwegian University of Science and Technology, Trondheim, $155 \mathrm{pp}$.

Howell, J.A., Skorstad, A., MacDonald, A., Fordham, A., Flint, S., Fjellvoll, B. \& Manzocchi, T. 2008: Sedimentological parameterization of shallow-marine reservoirs. Petroleum Geoscience 14, 17-34. https://doi.org/10.1144/1354-079307-787.

Husteli, B., Boxaspen, M.A. \& Rosseland Knutsen, E. 2014: Lateral variations in a tidally influenced Carnian to Early Norian transect in central Svalbard. European Geosciences Union General Assembly Conference Abstracts 16, 27 April-2 May, Vienna, Austria. http://meetingorganizer.copernicus.org/EGU2014/EGU2014-12654.pdf

Høy, T. \& Lundschien B.A. 2011: Triassic deltaic sequences in the northern Barents Sea. Geological Society of London Memoirs 35, 249-260.

Ichaso, A.A. \& Dalrymple, R.W. 2009: Tide- and wave-generated fluid mud deposits in the Tilje Formation (Jurassic), offshore Norway. Geology 37, 539-542. https://doi.org/10.1130/G25481A.1.

Johansen, S.K. 2016: Sedimentology and facies distribution of the Upper Triassic De Geerdalen Formation in the Storfjorden area and Wilhelmøya, eastern Svalbard. MSc thesis, Norwegian University of Science and Technology, Trondheim, 179 pp.

Johnson, H.D. \& Baldwin, C.T. 1996: Chapter 7 - Shallow clastic seas. In Reading, H.G. (ed.): Sedimentary environments: processes, facies and stratigraphy, Third edition, Blackwell Science, Oxford, pp. 232280.
Klausen, T.G. \& Mørk, A. 2014: Upper Triassic paralic deposits of the De Geerdalen Formation on Hopen: Outcrop analog to the subsurface Snadd Formation in the Barents Sea. American Association of Petroleum Geologists Bulletin 98, 1911-1941. https://doi.org/10.1306/02191413064.

Klausen, T.G., Ryseth, A.E., Helland-Hansen, W., Gawthorpe, R. \& Laursen, I. 2014: Spatial and temporal changes in geometries of fluvial channel bodies from the Triassic Snadd Formation of offshore Norway. Journal of Sedimentary Research 84, 567-585. https://doi.org/10.2110/jsr.2014.47.

Klausen, T.G., Ryseth, A.E., Helland-Hansen, W., Gawthorpe, R. \& Laursen, I. 2015: Regional development and sequence stratigraphy of the Middle to Late Triassic Snadd Formation, Norwegian Barents Sea. Marine and Petroleum Geology 62, 102-122. https://doi.org/10.1016/j.marpetgeo.2015.02.004.

Knarud, R. 1980: En sedimentologisk og diagenetisk undersøkelse av Kapp Toscana Formasjonens sedimenter på Svalbard. Cand. Real. thesis, University of Oslo, $208 \mathrm{pp}$.

Knutsen, E.R. 2013: Sedimentology of the Offshore-to Tide-Dominated Upper Triassic De Geerdalen Formation on Central Spitsbergen and Examples of Comparable Facies in the Equivalent Snadd Formation. MSc thesis, University of Bergen, $134 \mathrm{pp}$.

Krajewski, K.P. 2008: The Botneheia Formation (Middle Triassic) in Edgeøya and Barentsøya, Svalbard: lithostratigraphy, facies, phosphogenesis, paleoenvironment, Polish Polar Research 29, 319364.

Kraus, M.J. 1999: Palaeosols in clastic sedimentary rocks: their geologic applications. Earth-Science Reviews 47, 41-70. https://doi.org/10.1016/S0012-8252(99)00026-4.

Kraus, M.J. \& Aslan, A. 1999: Palaeosol sequences in floodplain environments: a hierarchical approach. Special Publication, International Association of Sedimentologists 27, 303-321.

Launis, A., Pott, C.P. \& Mørk, A. 2014: A glimpse into the Carnian: Late Triassic plant fossils from Hopen, Svalbard. Norwegian Petroleum Directorate Bulletin 11,129-136.

Li, W., Bhattacharya, J.P. \& Wang, Y. 2011: Delta asymmetry: concepts, characteristics, and depositional models. Petroleum Science 8, 278289. https://doi.org/10.1007/s12182-011-0145-x.

Lock, B.E., Pickton, C.A.G., Smith, D.G., Batten, D.J. \& Harland, W.B. 1978: The Geology of Edgeøya and Barentsøya, Svalbard. Norsk Polarinstitutt Skrifter Nr.168, 67 pp.

Lord, G.S., Solvi, K.H., Ask, M., Mørk, A., Hounslow, M.W. \& Paterson, N.W. 2014a: The Hopen Member: A new member of the Triassic De Geerdalen Formation, Svalbard. Norwegian Petroleum Directorate Bulletin 11, 81-96.

Lord, G.S., Solvi, K.H., Klausen, T.G. \& Mørk, A. 2014b: Triassic channel bodies on Hopen, Svalbard: Their facies, stratigraphic significance and spatial distribution. Norwegian Petroleum Directorate Bulletin $11,41-49$.

Lundschien, B.A., Høy, T. \& Mørk, A. 2014: Triassic hydrocarbon potential in the Northern Barents Sea: Integrating Svalbard and stratigraphic core data. Norwegian Petroleum Directorate Bulletin $11,3-20$.

Midtgaard, H.H. 1996: Inner-shelf to lower-shoreface hummocky sandstone bodies with evidence for geostrophic influenced combined flow, Lower Cretaceous, West Greenland. Journal of Sedimentary Research 66, 343-353. https://doi.org/10.1306/d4268342-2b26-11d7-8648000102c1865d.

Miller, E.L., Soloviev, A.V., Prokopiev, A.V., Toro, J., Harris, D., Kuzmichev, A.B. \& Gehrels, G.E. 2013: Triassic river systems and the paleo-Pacific margin of northwestern Pangea. Gondwana Research 23, 1631-1645. https://doi.org/10.1016/j.gr.2012.08.015.

Morad, S. 1998: Carbonate cementation in sandstones: distribution patterns and geochemical evolution. In Morad, S. (ed.): Carbonate cementation in sandstones, International Association of Sedimentologists Special Publication 26, pp. 1-26. https://doi.org/10.1002/9781444304893.ch1. 
Myrow, P.M., Lukens, C., Lamb, M.P., Houck, K. \& Strauss, J. 2008: Dynamics of a transgressive prodeltaic system; implications for geography and climate within a Pennsylvanian intracratonic basin, Colorado, USA. Journal of Sedimentary Research 78, 512-528. https://doi.org/10.2110/jsr.2008.061.

Mørk, A. \& Bjorøy, M. 1984: Mesozoic source rocks on Svalbard. In Spencer A.M. (ed.): Petroleum Geology of the North European Margin, Norwegian Petroleum Society, Graham \& Trotman, London, pp. 371-382. https://doi.org/10.1007/978-94-009-5626-1_28.

Mørk, A. \& Bromley, R.G. 2008: Ichnology of a marine regressive systems tract: the Middle Triassic of Svalbard. Polar Research 27,339-359. http://onlinelibrary.wiley.com/doi/10.1111/j.1751-8369.2008.00077.x/full.

Mørk, A., Knarud, R. \& Worsley, D. 1982: Depositional and Diagenetic Environments of the Triassic and Lower Jurassic Succession of Svalbard. In Embry, A.F. \& Balkwill, H.R. (eds.): Arctic Geology and Geophysics, Canadian Society of Petroleum Geologists Memoir 8, pp. 371-398.

Mørk, A., Dallmann, W.K., Dypvik, H., Johannessen, E.P., Larssen, G.B., Nagy, J., Nøttvedt, A., Olaussen, S., Pčelina, T.M. \& Worsley, D. 1999a: Mesozoic Lithostratigraphy. In Dallmann, W.K. (ed.): Lithostratigraphic Lexicon of Svalbard, Upper Paleozoic to Quaternary Bedrock - Review and recommendations for nomenclature use, Norwegian Polar Institute, Tromsø, pp. 127-214.

Mørk, A., Elvebakk, G., Forsberg, A.W., Hounslow, M.W., Nakrem, H.A., Vigran, J.O. \& Weitschat, W. 1999b: The type section of the Vikinghøgda Formation: a new Lower Triassic unit in central and eastern Svalbard. Polar Research 18, 51-82. https://doi.org/10.3402/polar.v18i1.6558.

Mørk, A., Lord, G.S., Solvi, K.H. \& Dallmann, W.K. 2013: Geological Map of Svalbard, sheet G14G Hopen, scale 1:100,000, Norsk Polarinstitutt Temakart 50.

Mørk, M.B.E. 1999: Compositional variations and provenance of Triassic sandstones from the Barents Shelf. Journal of Sedimentary Research 69, 690-710. https://doi.org/10.2110/jsr.69.690.

Mørk, M.B.E. 2013: Diagenesis and quartz cement distribution of lowpermeability Upper Triassic-Middle Jurassic reservoir sandstones, Longyearbyen CO2 lab well site in Svalbard, Norway. American Association of Petroleum Geologists Bulletin 97, 577-596.

Nichols, G. 2009: Sedimentology and Stratigraphy, Second edition. River Street, Hoboken, USA, 419 pp.

Nystuen, J.P., Andresen, A., Kumpulainen, R.A. \& Siedlecka, A. 2008: Neoproterozoic basin evolution in Fennoscandia, East Greenland and Svalbard. Episodes 31, 35-43.

Nøttvedt, A. \& Kreisa, R.D. 1987: Model for the combined-flow origin of hummocky cross-stratification. Geology 15, 357-361. https://doi.org/10.1130/0091-7613(1987)15<357:MFTCOO>2.0.CO;2.

Olariu, C. 2014: Autogenic process change in modern deltas. In Martinius, A.W., Ravnås, R., Howell, J.A., Steel, R.J. \& Wonham, J.P. (eds.): From Depositional Systems to Sedimentary Successions on the Norwegian Continental Margin, International Association of Sedimentologists Special Publication 46, pp. 149-166. https://doi.org/10.1002/9781118920435.ch7.

Olariu, C. \& Bhattacharya, J.P. 2006: Terminal distributary channels and delta front architecture of river-dominated delta systems. Journal of Sedimentary Research 76, 212-233. https://doi.org/10.2110/jsr.2006.026.

Olariu, C., Steel, R.J. \& Petter, A.L. 2010: Delta-front hyperpycnal bed geometry and implications for reservoir modeling: Cretaceous Panther Tongue delta, Book Cliffs, Utah. American Association of Petroleum Geologists Bulletin 94, 819-845. https://doi.org/10.1306/11020909072.

Olaussen, S., Husteli, B., Lord, G.S., Rismyhr, B., Johannessen, E.P. \& Mørk, A. 2015: The Early Norian transition in Svalbard and the Barents Sea: A record of slowing down of basin subsidence, alteration of facies associations and shift of provenance and climate change. 2nd Boreal Triassic Conference 2015, Svalbard. Abstract and proceedings Geological Society of Norway, 39-42.
Osmundsen, P.T., Braathen, A., Rød, R.S. \& Hynne, I. 2014: Styles of normal faulting and fault controlled deposition in the Triassic of Hopen and Edgeøya, Svalbard. Norwegian Petroleum Directorate Bulletin 11, 61-80.

Paterson, N.W. \& Mangerud, G. 2015: Late Triassic (Carnian Rhaetian) palynology of Hopen, Svalbard. Review of Paleobotany and Palynology 220, 98-119. https://doi.org/10.1016/j.revpalbo.2015.05.001.

Paterson, N.W., Mangerud, G., Cetean, C.G., Mørk, A., Lord, G.S., Klausen, T.G. \& Mørkved, P.T. 2016: A multidisciplinary biofacies characterization of the Late Triassic (late Carnian-Rhaetian) Kapp Toscana Group on Hopen, Arctic Norway. Palaeogeography Palaeoclimatology Palaeoecology 464, 16-42. https://doi.org/10.1016/j.palaeo.2015.10.035.

Pčelina, T.M. 1983: Novye dannye po stratigrafii mezozoja arhipelaga Špicbergen. (New material on the Mesozoic stratigraphy of the Spitsbergen Archipelago.) In Krasil'ščikov, A.A. \& Basov, V.A. (eds.): Geologija Špicbergena. (The geology of Spitsbergen.), Leningrad: Production-Geological Association Sevmorgeologija, pp. 121-141.

Pettijohn, F.J., Potter, P.E. \& Siever, R. 1987: Sand and Sandstone, Second Edition. Springer-Verlag, New York, 553 pp. https://doi.org/10.1007/978-1-4612-1066-5.

Puchkov, V.N. 2009: The evolution of the Uralian orogen. Geological Society of London Special Publications 327, 161-195. https://doi.org/10.1144/SP327.9.

Reading, H.G. \& Collinson, J.D. 1996: Chapter 6 - Clastic coasts. In Reading, H.G. (ed.): Sedimentary environments: processes, facies and stratigraphy, Third edition, Blackwell Science, Oxford, pp. 154-231.

Reineck, H.E. \& Singh, I.B. 1980: Depositional Sedimentary Environments, Second Edition. Springer-Verlag, Berlin Heidelberg, 549 pp. https://doi.org/10.1007/978-3-642-81498-3.

Reinson, G.E. 1992: Transgressive barrier island and estuarine systems. In Walker, R.G. \& James, N.P. (eds.): Facies Models: Response to Sea Level Change, Geological Association of Canada, Wiley \& Sons, Hoboken, New Jersey, pp. 179-194. https://doi.org/10.1002/gj.3350290317.

Retallack, G.J. 1991: Untangling the effects of burial alteration and ancient soil formation. Annual Review of Earth and Planetary Sciences 19, 183-206. https://doi.org/10.1146/annurev.ea.19.050191.001151.

Reynolds, A.D. 1999: Dimensions of paralic sandstone bodies. American Association of Petroleum Geologists Bulletin 83, 211-229. https://doi.org/10.1306/00aa9a48-1730-11d7-8645000102c1865d.

Riis, F., Lundschien, B.A., Høy, T., Mørk, A. \& Mørk, M.B.E. 2008: Evolution of the Triassic shelf in the northern Barents Sea region. Polar Research 27, 318-338.

https://doi.org/10.1111/j.1751-8369.2008.00086.x.

Rød, R.S., Hynne, I.B. \& Mørk, A. 2014: Depositional environment of the Upper Triassic De Geerdalen Formation - An E-W transect from Edgeøya to Central Spitsbergen, Svalbard. Norwegian Petroleum Directorate Bulletin 11, 21-40.

Scholle, P.A. \& Spearing, D. 1982: Sandstone Depositional Environments. The American Association of Petroleum Geologists, Yulsa, Oklahoma, 392pp.

Schumm, S.A. 1972: Fluvial paleochannels. In Rigby, J.K. \& Hamblin, W.K. (eds.): Recognition of Acient Sedimentary Environments, Society for Sedimentary Geology Special Publication 16, pp. 98-107. https://doi.org/10.2110/pec.72.02.0098.

Smith, D.G., Harland, W.B. \& Hughes, N.F. 1975: The Geology of Hopen, Svalbard. Geological Magazine 112, 1-23. https://doi.org/10.1017/S0016756800045544.

Solvi, K.H. 2013: Visualize and interpret the geometry, heterogeneity and lateral continuation of channel bodies in the De Geerdalen Formation at Hopen. MSc thesis, Norwegian University of Science and Technology, Trondheim, $122 \mathrm{pp}$.

Støen, S.J. 2016: Late Triassic sedimentology and diagenesis of Barentsøya, Wilhelmøya and eastern Spitsbergen. MSc thesis, Norwegian University of Science and Technology, Trondheim, 165 pp. 
Torsvik, T.H. \& Cocks, L.R.M. 2004: Earth geography from 400 to 250 million years: a paleomagnetic, faunal and facies review. Journal of the Geological Society of London 161, 555-572. https://doi.org/10.1144/0016-764903-098.

Torsvik, T.H., Van der Voo, R., Preeden, U., Mac Niocaill, C., Steinburger, B., Doubrovine, P.V., van Hinsbergen, D.J.J., Domeier, M., Gaina, C., Tohver, E., Meert, J.G., McCausland, P.J.A. \& Cocks, L.R.M. 2012: Phanerozoic polar wander, paleogeography and dynamics. Earth Sciences Review 114, 325-368. https://doi.org/10.1016/j.earscirev.2012.06.007.

Tugarova, M.A. \& Fedyaevsky, A.G. 2014: Calcareous microbialites in the Upper Triassic succession of Eastern Svalbard. Norwegian Petroleum Directorate Bulletin 11,137-152.

Tye, R.S. 2004: Geomorphology: An approach to determining subsurface reservoir dimensions. American Association of Petroleum Geologists Bulletin 88, 1123-1147. https://doi.org/10.1306/02090403100.

Van Wagoner, J.C., Mitchum, R., Campion, K. \& Rahmanian, V. 1990: Siliciclastic sequence stratigraphy in well logs, cores, and outcrops: concepts for high-resolution correlation of time and facies. American Association of Petroleum Geologists Methods in Exploration Series 7, 1-55.

Vigran, J.O., Mangerud, G., Mørk, A., Worsley, D. \& Hochuli, P.A. 2014: Palynology and geology of the Triassic succession of Svalbard and the Barents Sea. Geological Survey of Norway Special Publication 14, $1-269$.

Webb, G.E. 1994: Paleokarst, paleosol, and rocky-shore deposits at the Mississippian-Pennsylvanian unconformity, northwestern Arkansas. Geological Society of America Bulletin 106, 634-648. https://doi.org/10.1130/0016-7606(1994)106<0634:PPARSD>2.3.CO;2.

Winsnes, T. 1981: Geological Map of Svalbard, sheet 2G, Edgeøya, scale 1:500,000, Norsk Polarinstitutt Skrifter 154B (map).

Winsnes, T. \& Worsley, D. 1981: Geological Map of Svalbard, sheet 2G, Edgeøya, scale 1:500,000, Norsk Polarinstitutt Skrifter 154B (text).

Worsley, D. 1973: The Wilhelmøya Formation - a new lithostratigraphic unit from the Mesozoic of Eastern Svalbard. Norsk Polarinstitutt Årbok 1971,7-16.

Worsley, D. 2008: The post Caledonian development of Svalbard and the western Barents Sea. Polar Research 27, 298-317. https://doi.org/10.1111/j.1751-8369.2008.00085.x.

Yang, B., Dalrymple, R.W. \& Chun, S. 2006: The significance of hummocky cross-stratification (HCS) wavelengths; evidence from an open-coast tidal flat, South Korea. Journal of Sedimentary Research 76, 2-8. https://doi.org/10.2110/jsr.2006.01. 